\title{
Jadomycins Inhibit Type II Topoisomerases and Promote DNA Damage and Apoptosis in Multidrug-Resistant Triple-Negative Breast Cancer Cells $\mathbf{s}$
}

\author{
Steven R. Hall, Jay Toulany, Leah G. Bennett, Camilo F. Martinez-Farina, \\ Andrew W. Robertson, David L. Jakeman, and Kerry B. Goralski \\ Department of Pharmacology, Faculty of Medicine (S.R.H., K.B.G.), College of Pharmacy, Faculty of Health (J.T., L.G.B, D.L.J., \\ K.B.G.), and Department of Chemistry, Faculty of Sciences (C.F.M.-F., A.W.R., D.L.J.), Dalhousie University, Halifax, Nova \\ Scotia, Canada
}

Received March 1, 2017; accepted September 7, 2017

\begin{abstract}
Jadomycins are natural products that kill drug-sensitive and multidrug-resistant (MDR) breast cancer cells. To date, the cytotoxic activity of jadomycins has never been tested in MDR breast cancer cells that are also triple negative. Additionally, there is only a rudimentary understanding of how jadomycins cause cancer cell death, which includes the induction of intracellular reactive oxygen species (ROS). We first created a paclitaxel-resistant, triple-negative breast cancer cell line [paclitaxel-resistant MDA-MB-231 breast cancer cells (231-TXL)] from drug-sensitive control MDA-MB-231 cells (231-CON). Using thiazolyl blue methyltetrazolium bromide cell viability-measuring assays, jadomycins $B, S$, and $F$ were found to be equipotent in drug-sensitive 231-CON and MDR 231-TXL cells; and using ROSdetecting assays, these jadomycins were determined to increase ROS activity in both cell lines by up to 7.3-fold. Jadomycins
\end{abstract}

caused DNA double-strand breaks in 231-CON and 231-TXL cells as measured by $\gamma \mathrm{H} 2 \mathrm{AX}$ Western blotting. Coincubation with the antioxidant $\mathrm{N}$-acetyl cysteine or pro-oxidant auranofin did not affect jadomycin-mediated DNA damage. Jadomycins induced apoptosis in 231-CON and 231-TXL cells as measured by annexin V affinity assays, a process that was retained when ROS were inhibited. This indicated that jadomycins are capable of inducing MDA-MB-231 apoptotic cell death independently of ROS activity. Using quantitative polymerase chain reaction, Western blotting, and direct topoisomerase inhibition assays, it was determined that jadomycins inhibit type II topoisomerases and that jadomycins B and $\mathrm{F}$ selectively poison topoisomerase $\| l \beta$. We therefore propose novel mechanisms through which jadomycins induce breast cancer cell death independently of ROS activity, through inhibition or poisoning of type II topoisomerases and the induction of DNA damage and apoptosis.

\section{Introduction}

Breast cancers are among the most common types of cancer to affect women worldwide (Yu et al., 2013). Despite progress in its treatment as a local disease, metastatic breast cancer

K.B.G. received research infrastructure funding from the Canadian Foundation for Innovation Leaders Opportunity Fund. The research was supported by operating grants from the Canadian Breast Cancer FoundationAtlantic Chapter, the Dalhousie Pharmacy Endowment, the Beatrice Hunter Cancer Research Institute, and the Dalhousie University Faculty of Health Professions to K.B.G.; and from the Nova Scotia Health Research Foundation, the Natural Sciences and Engineering Research Council, and the Canadian Institutes of Health Research to D.L.J. S.R.H. was supported by a Nova Scotia Health Research Foundation Scotia Scholar Award and a Level 2 Izaak Walton Killam Predoctoral Scholarship.

Preliminary results of this work have been presented and abstracts published for the following meetings: Canadian Society of Pharmacology and Therapeutics Annual Meeting, 7-10 June 2015, Toronto, ON, Canada; EACRAACR-SIC Special Conference 2015, Anticancer Drug Action and Drug Resistance: from Cancer Biology to the Clinic, 20-23 June 2015, Florence, Italy; 2016 Beatrice Hunter Cancer Research Institute (BHCRI)/Terry Fox Research Institute (TFRI) Cancer Research Conference in Atlantic Canada: Recent Advances in Cancer Research, 8 November 2016, Halifax, NS, Canada; American Society of Pharmacology and Experimental Therapeutics Annual Meeting at Experimental Biology 2017, 22-26 April 2017, Chicago, IL; and Canadian Society of Pharmacology and Therapeutics 2017 Annual Meeting, 14-16 June 2017, Halifax, NS, Canada.

https://doi.org/10.1124/jpet.117.241125.

S This article has supplemental material available at jpet.aspetjournals.org. remains essentially incurable with a median survival time of 2-3 years (Morris et al., 2009; Lluch et al., 2014). Its incurability is primarily due to the development of multidrug resistance (MDR) within the cancerous cells, reducing the effectiveness of available therapies (Morris et al., 2009; Rivera, 2010). The most commonly observed mechanism of MDR is the overexpression of ATP-binding cassette (ABC) efflux transporters, which expel chemotherapeutic agents from within the cell, rendering the treatments ineffective. In cell culture, the ABCB1, ABCC1, and ABCG2 transporters are most likely to be overexpressed in MDR tissue samples (Szakács et al., 2006).

Additionally, certain categories of breast cancer are innately more difficult to treat than others. Breast tumor cells that lack or have little expression of estrogen receptor and progesterone receptor and do not overexpress human epidermal growth factor receptor 2 (HER2) are known as triplenegative breast cancers. Triple-negative breast cancers are typically of a larger size and higher grade than non-triplenegative breast cancers, with a higher rate of metastasis development and a lower overall survival rate. About $15 \%$ of all breast cancers are triple negative, and they disproportionally affect women under the age of 40 years. Treatment options for triple-negative breast cancer are limited because 
hormone receptor or HER2-targeted therapies are ineffective, and for advanced cases the only treatments available are cytotoxic chemotherapies (Bauer et al., 2007; Rakha et al., 2007; Elias, 2010). With up to $30 \%$ of all cases of breast cancer ultimately metastasizing and the high prevalence of MDR and triple-negative breast cancers (Elias, 2010; Rivera, 2010), new and more effective treatments are needed.

Jadomycins (Fig. 1, a-d) are a class of naturally biosynthesized, polyketide-derived compounds produced by the soil bacteria Streptomyces venezuelae ISP5230 (Jakeman et al., 2006). Jadomycin analogs with distinct functional groups on the oxazolone ring can be biosynthesized by using different amino acids as the sole nitrogen source in the bacterial growth medium (Dupuis et al., 2012; Martinez-Farina and Jakeman, 2015; Robertson et al., 2015). We have shown that many jadomycin analogs are effective cytotoxic agents against estrogen receptor-positive, progesterone receptor-positive, HER2-negative MCF7 breast cancer cells and that they largely retain their potency in MDR MCF7 breast cancer cells that overexpress the $\mathrm{ABC}$ drug efflux transporters $A B C B 1$, $A B C C 1$, or $A B C G 2$. In comparison, drugs that are known $A B C$ transporter substrates lose their cytotoxic potency, such as with doxorubicin (DOX), etoposide, or mitoxantrone (Fig. 1, e-g) (Issa et al., 2014). We have also determined that jadomycins are equally cytotoxic in triple-negative MDA-MB-231 versus non-triple-negative MCF7, BT474, and SKBR3 breast cancer cells (Hall et al., 2015). Jadomycins are therefore attractive compounds for the treatment of drug-resistant and triplenegative breast cancers.

Currently, we only have a basic understanding of how jadomycins exert their anticancer activity. We initially determined that these compounds induce intracellular ROS activity through a $\mathrm{Cu}(\mathrm{II})$-dependent mechanism in drugsensitive and MDR $A B C B 1$-overexpressing MCF7 breast cancer cells, and that jadomycin potency can be altered when cotreated with antioxidants or pro-oxidants, suggesting that jadomycin anticancer activity is at least partially dependent on ROS. Interestingly, it was also found that when ROS were inhibited, jadomycins still retained $100 \%$ cytotoxic efficacy in the breast cancer cells (albeit with lower potency), evidencing that jadomycins are also acting through ROS-independent mechanisms (Hall et al., 2015). One such alternate mechanism is the inhibition of aurora B kinase, an important mitotic protein, which can lead to cancer cell death (Fu et al., 2008; Issa et al., 2014; Hall et al., 2015). Jadomycins may also interact with topoisomerase II $\beta$, an enzyme that reduces DNA tension during replication, to which jadomycin DS was recently discovered to bond (Martinez-Farina et al., 2015). The polypharmacological nature of the anticancer activity of jadomycins could help explain how these compounds evade drug resistance.

To date, we have only tested the mechanisms of jadomycin anticancer activity in MCF7 breast cancer cells (Issa et al., 2014; Hall et al., 2015). To advance our previous work, a more aggressive triple-negative cell line, MDA-MB-231, was chosen for this study. Additionally, although we determined that jadomycins kill MDR and drug-sensitive breast cancer cells (Issa et al., 2014), a better understanding of their intracellular cytotoxic targets and mechanisms of action are still needed. Building on our past experiments that determined jadomycins induce ROS (Hall et al, 2015) and because oxidative stress can cause DNA damage and apoptosis (Bertram and Hass, 2008), we hypothesized that jadomycins damage DNA, leading to breast cancer cell apoptosis.

\section{Materials and Methods}

Chemical and Biologic Materials. Thiazolyl blue methyltetrazolium bromide (MTT), NAC, methanol, propidium iodide, mitoxantrone, paclitaxel (TXL), DOX, agarose, benzamide, $\mathrm{CaCl}_{2}, \mathrm{NaCl}$, Tris-HCl, Tris base, HEPES, $\mathrm{KCl}, \mathrm{MgCl}_{2}$, Na-EDTA, SDS, dimethylsulfoxide, glycerol, sucrose, ATP, bovine serum albumin, ethidium bromide, proteinase $\mathrm{K}$, bromophenol blue, and phosphate-buffered saline (PBS) were purchased from Sigma-Aldrich (Oakville, ON, Canada). Auranofin was purchased from Santa Cruz Biotechnology (Dallas, TX). Molecular biology grade water, Dulbecco's modified Eagle's medium, fetal bovine serum (FBS), penicillin and streptomycin, sodium pyruvate, 5-(and 6-)chloromethyl-2' $7^{\prime}$-dichlorodihydrofluorescein diacetate $\left(\mathrm{CM}-\mathrm{DCFH}_{2}-\mathrm{DA}\right)$, Super Script II Reverse Transcriptase, dithiothreitol, and TrypLE Express were purchased from Thermo Fisher Scientific (Burlington, ON, Canada). Annexin-VFLUOS was purchased from Roche Diagnostics (Indianapolis, IN). The cell fractionation kit, Z-VAD(OMe)-FMK, mouse monoclonal to $\gamma \mathrm{H} 2 \mathrm{AX}$ (phospho S139) antibody, mouse monoclonal to topoisomerase II $\alpha$ antibody, and rabbit polyclonal to Histone H3 antibody were purchased from Abcam (Toronto, ON, Canada). Blocking buffer, IRDye 680RD-conjugated donkey anti-mouse antibody, and IRDye 800CW-conjugated goat anti-rabbit antibody were purchased from Mandel Scientific (Guelph, ON, Canada). SsoAdvanced Universal SYBR Green Supermix was purchased from BIO-RAD (Mississauga, ON, Canada). Kinetoplast DNA, pHOT1 DNA, purified topoisomerase II $\alpha$, and $5 \times$ stop buffer were purchased from TopoGEN (Buena Vista, CO). Purified topoisomerase II $\beta$ was provided by Dr. Neil Osheroff and Jo Ann Byl (Vanderbilt University, Nashville, TN).

Production of Jadomycins. Jadomycins B, S, and F were isolated and characterized as previously described (Jakeman et al., 2009; Dupuis et al., 2011, 2012; Issa et al., 2014).

Cell Lines. The control MDA-MB-231 (231-CON) breast cancer cells were kindly provided by Drs. David Hoskin and Anna Greenshields (Dalhousie University, Halifax, NS, Canada). The polyclonal TXL-resistant MDA-MB-231 (231-TXL) cells were created in-house using slowly increasing concentrations of TXL (Sigma-Aldrich) over 7 months until a final concentration of $470 \mathrm{nM}$ was reached. All MDAMB-231 cells were cultured in phenol red-free Dulbecco's modified Eagle's medium supplemented with $10 \% \mathrm{FBS}, 100 \mathrm{IU} / \mathrm{ml}$ penicillin, $250 \mu \mathrm{g} / \mathrm{ml}$ streptomycin, and $1 \mathrm{mM}$ sodium pyruvate (standard assay medium; Thermo Fisher Scientific), with the 231-TXL cells maintained with $470 \mathrm{nM}$ TXL. The cells were split, and growth medium was changed every 3-4 days up to a maximum of 35 passages. Cells were maintained in a humidified, $95 \%$ air $/ 5 \% \mathrm{CO}_{2}$ atmosphere at $37^{\circ} \mathrm{C}$ (standard conditions).

RNA Isolation, Reverse Transcription, and Quantitative Real-Time Polymerase Chain Reaction. Total RNA was isolated from lysates of 231-CON and 231-TXL cells 1) with no drug treatment;

ABBREVIATIONS: ANOVA, analysis of variance; ABC, ATP-binding cassette; CM-DCFH 2 -DA, 5-(and 6-)chloromethyl-2'7'-dichlorodihydrofluorescein diacetate; 231-CON, control MDA-MB-231 breast cancer cell; DOX, doxorubicin; FBS, fetal bovine serum; GAPDH, glyceraldehyde phosphate dehydrogenase; HER2, human epidermal growth factor receptor 2; kDNA, kinetoplast DNA; MDR, multidrug resistance; MTT, thiazolyl blue methyltetrazolium bromide; NAC, $N$-acetyl cysteine; PARP, poly(ADP-ribose) polymerase; PBS, phosphate-buffered saline; PCR, polymerase chain reaction; PPIA, peptidylprolyl isomerase A; ROS, reactive oxygen species; TXL, paclitaxel (Taxol); 231-TXL, paclitaxel-resistant MDA-MB-231 breast cancer cell; Z-VAD, N-benzyloxycarbonyl-Val-Ala-Asp(O-Me) fluoromethyl ketone (Z-VAD[OMe]-FMK). 
A<smiles>[R]C1C(=O)O[C@@H]2c3cc(C)cc(O)c3C3=C(C(=O)c4c5cccc4C(=O)[C@@H](C[C@@H]4C(C)C(O)[C@H](O)[C@H]4O)O5)N1C32</smiles>

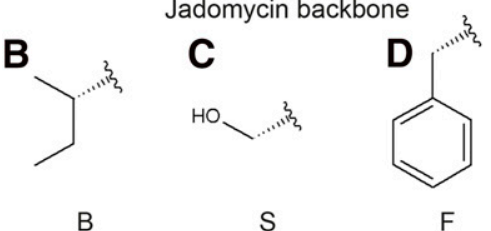

E<smiles>COc1cccc2c1C(=O)C1C(O)=C3C(=C(O)C1C2=O)C[C@](O)(C(=O)CO)C[C@@H]3O[C@H]1C[C@H](N)[C@H](O)[C@H](C)O1</smiles>

Doxorubicin
$\mathbf{F}$

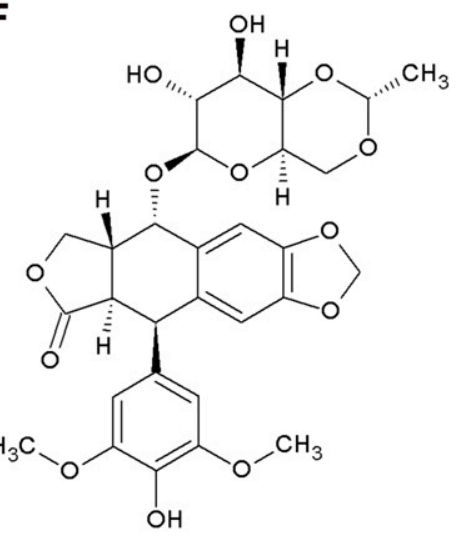

Etoposide

G<smiles>COCCNC1=CC=C(NCCNCCO)C2C(=O)c3c(O)ccc(O)c3C(=O)C12</smiles>

Fig. 1. Chemical structures of drug treatments used. Jadomycin backbone (a); alternate jadomycin analogs differ at the indicated "R"-group, such as with jadomycins B (b) , S (c), and F (d) (Issa et al., 2014). Control chemotherapeutic drugs used were DOX (e), etoposide (f), and mitoxantrone (g) (https://chem.nlm.nih.gov/ chemidplus/sid). or 2) treated with jadomycin $\mathrm{B}, \mathrm{S}$, or $\mathrm{F}(20 \mu \mathrm{M})$, mitoxantrone $(1 \mu \mathrm{M})$, or 1:7 methanol/ $\mathrm{H}_{2} \mathrm{O}$ vehicle control (jadomycin vehicle) for 36 hours under standard conditions using the Aurum Total RNA Mini Kit (BIO$\mathrm{RAD})$ according to the manufacturer instructions. Isolated RNA ( 0.5 $\mu \mathrm{g})$ was reverse transcribed to complementary DNA using Super Script II Reverse Transcriptase (Thermo Fisher Scientific). The complementary DNA was amplified via quantitative polymerase chain reaction (PCR) using $125 \mathrm{nM}$ gene-specific primers (Table 1) in a total volume of $20 \mu \mathrm{l}$ using an SYBR Green PCR Supermix (BIORAD), and a Step One Plus real-time PCR thermocycler (Applied Biosystems, Foster City, CA) in duplicate for each primer set. Gene expression was normalized using the average of the three housekeeping genes glyceraldehyde phosphate dehydrogenase (GAPDH), $\beta$-actin, and peptidylprolyl isomerase A [(PPIA (also known as cyclophilin A)] via the $\Delta \Delta C_{t}$ method (Livak and Schmittgen, 2001).

MTT Viability Assays. MTT assays were used to evaluate the anticancer activity of jadomycins $\mathrm{B}, \mathrm{S}$, and $\mathrm{F}(0.1-20 \mu \mathrm{M})$ and the $\mathrm{ABCB} 1$ substrates mitoxantrone $(0.1 \mathrm{nM}$ to $50 \mu \mathrm{M})$ and $\mathrm{DOX}(0.5 \mathrm{nM}$ to $100 \mu \mathrm{M})$ in 231-CON and 231-TXL breast cancer cells and were completed according to our previously described methods (Issa et al., 2014).
ROS Measuring Assays. To quantify the presence of intracellular ROS in 231-CON and 231-TXL cells, a fluorescent assay utilizing the ROS-reactive CM-DCFH ${ }_{2}$-DA (Thermo Fisher Scientific) was used as previously described (Hall et al., 2015) with minor alterations. Briefly, on day 1, 20,000 cells were seeded in each well of a black-sided, clearbottomed 96-well plate. On day 2, the medium was removed and replaced with $100 \mu \mathrm{l}$ of $1 \% \mathrm{FBS}$ standard assay medium that contained 7.5 $\mu \mathrm{M}$ CM-DCFH ${ }_{2}$-DA for 1 hour under standard conditions. The medium containing $\mathrm{CM}^{-\mathrm{DCFH}} \mathrm{C}_{2}$-DA was then removed, wells were washed with PBS, and the cells were 1) treated with $100 \mu$ l of jadomycin $\mathrm{B}, \mathrm{S}$, or $\mathrm{F}(2.5-40 \mu \mathrm{M})$ or vehicle in $1 \% \mathrm{FBS}$ standard assay medium for 24 hours in triplicate; 2) treated with $100 \mu \mathrm{l}$ of jadomycin $\mathrm{B}, \mathrm{S}$, or $\mathrm{F}$ $(40 \mu \mathrm{M}), \mathrm{DOX}(40 \mu \mathrm{M}), \mathrm{H}_{2} \mathrm{O}_{2}(40 \mathrm{mM})$, or vehicle in $1 \% \mathrm{FBS}$ standard assay medium for $0,1,2,4,6,8,12$, or 24 hours in triplicate; or 3 ) pretreated with $80 \mu \mathrm{l}$ of control medium, NAC, or auranofin (final concentrations of $2.5 \mathrm{mM}$ and $1 \mu \mathrm{M}$, respectively) for 1 hour and then treated with $20 \mu \mathrm{l}$ of jadomycin $\mathrm{B}, \mathrm{S}$, or $\mathrm{F}$ (final concentrations of $5-20 \mu \mathrm{M})$ in $1 \%$ FBS standard assay medium for 24 hours in triplicate.

Western Blot Analysis. The 231-CON or 231-TXL breast cancer cells were seeded in 6 -well plates at 400,000 cells/well and left to

TABLE 1

PCR primers used to determine the expression of relevant genes in 231-CON and 231-TXL cells

\begin{tabular}{lll}
\hline \multicolumn{1}{c}{ Gene } & PCR Forward Primers $\left(5^{\prime}-3^{\prime}\right)$ & \multicolumn{1}{c}{ PCR Reverse Primers $\left(5^{\prime}-3^{\prime}\right)$} \\
\hline$A B C B 1$ & AGGCCAACATACATGCCTTC & CCTTCTCTGGCTTTGTCCAG \\
$A B C C 1$ & AGGTGGACCTGTTTCGTGAC & TCCACCAGAAGGTGATCCTC \\
$A B C G 2$ & TTATCCGTGGTGTGTCTGGA & TTCCTGAGGCCAATAAGGTG \\
TOP1 & AGTCCGGCATGATAACAAGG & GCCGAGCAGTCTCGTATTTC \\
TOP2A & TGGCTGAAGTTTGCCTTCT & GGCCTTCTAGTTCCACACCA \\
TOP2B & GAGTGGCTTGTGGGATGTT & TGTGCTTCTTTCCAGGCTTT \\
GAPDH & GAGTCAACGGATTTGGTCGT & TTGATTTGGGGGGATCTCG \\
$\beta-a c t i n$ & GGACTTCGAGCAAGAGATGG & AGCACTGTGTTGGCGTACAG \\
PPIA & ACCGCCGAGGAAAACCGTGT & CTGTCTTTGGGACCTTGTCTGCA \\
\hline
\end{tabular}


adhere overnight in standard assay medium at standard conditions. They were then either 1) treated in triplicate for 24 hours with control medium, jadomycin vehicle, jadomycin $\mathrm{B}, \mathrm{S}$, or $\mathrm{F}(15 \mu \mathrm{M})$, or mitoxantrone $(1 \mu \mathrm{M})$; or 2$)$ pretreated in triplicate for 1 hour with NAC, auranofin, or benzamide ( $2.5 \mathrm{mM}, 1 \mu \mathrm{M}$, and $5 \mathrm{mM}$, respectively) then treated with jadomycin $\mathrm{S}(15 \mu \mathrm{M})$ or jadomycin vehicle for 24 hours. The triplicate samples for each treatment were pooled, and the cytosolic, mitochondrial, and nucleic proteins were then fractionated and collected using a Cell Fractionation Kit (ab109719; Abcam) as per the manufacturer instructions. Protein content in each fraction was measured using the method of Lowry et al. (1951). Nucleic protein was separated on a $15 \%$ or $6 \%$ SDS-PAGE (for $\gamma \mathrm{H} 2 \mathrm{AX}$ and topoisomerase II $\alpha$ Western blots, respectively) and transferred to a nitrocellulose membrane. Membranes were incubated overnight in either 1) a 1:1000 dilution of a mouse monoclonal $\gamma \mathrm{H} 2 \mathrm{AX}$ (phospho S139) antibody (ab26350; Abcam) and a rabbit polyclonal Histone H3 antibody (ab1791; Abcam) or 2) a 1:500 dilution of a mouse monoclonal topoisomerase II $\alpha$ antibody (ab180393; Abcam) and a 1:20,000 dilution of rabbit polyclonal to Histone $\mathrm{H} 3$ antibody at $4^{\circ} \mathrm{C}$. After washing, membranes were incubated in 1:10,000 dilutions of IRDye 680RD-conjugated donkey anti-mouse and IRDye 800CW-conjugated goat anti-rabbit secondary antibodies (926-68072 and 926-32211, respectively; Mandel Scientific) for 1 hour at room temperature. For visualization of $\gamma \mathrm{H} 2 \mathrm{AX}$ and Histone $\mathrm{H} 3$, membranes were scanned at 700- and 800-nm infrared wavelengths, using a LI-COR Odyssey Scanner (Mandel Scientific). The pixel intensity of each $\gamma \mathrm{H} 2 \mathrm{AX}$ band was normalized to the intensity of the respective Histone H3 bands using ImageJ, and these ratios were expressed as a fold change versus the control medium-treated MDA-MB-231 cells.

Flow Cytometric Analysis of Apoptosis. Flow cytometric analysis of 231-CON and 231-TXL cells stained with annexin-V-FLUOS and propidium iodide was used to determine whether jadomycins induced apoptosis. On day 1 , cells were seeded at 50,000 cells/well into 12-well flat-bottomed plates and left to adhere overnight. On day 2, cells were treated with jadomycin $\mathrm{B}, \mathrm{S}$, or $\mathrm{F}(1.25-30 \mu \mathrm{M})$ or the positive control mitoxantrone $(0.1-1 \mu \mathrm{M})$, with or without a 1-hour pretreatment of auranofin, benzamide, Z-VAD, or NAC $(1 \mu \mathrm{M}, 5 \mathrm{mM}$, $100 \mu \mathrm{M}$, and $2.5 \mathrm{mM}$, respectively) or vehicle control, in $500 \mu \mathrm{l}$ of standard assay medium for 24-48 hours, depending on which time point best exemplified the effects of the cotreatment. Nonadherent and adherent cells were combined in 5 -ml round bottom tubes (Corning, Corning, NY), which were harvested using TrypLE Express (Thermo Fisher Scientific). Cells were washed with PBS and labeled with annexin-V-FLUOS (Roche Diagnostics) diluted as per the manufacturer instructions and propidium iodide $(1 \mu \mathrm{g} / \mathrm{ml}$; SigmaAldrich) in detection buffer (10 mM HEPES, $140 \mathrm{mM} \mathrm{NaCl}$, and $5 \mathrm{mM}$ $\mathrm{CaCl}_{2}$ ) for 15 minutes at room temperature. Each sample was then diluted with $300 \mu \mathrm{l}$ of cold detection buffer and analyzed by flow cytometry using a FACSCalibur Flow Cytometer (Becton Dickinson, Franklin Lakes, NJ). The percentage of healthy, early apoptotic, and late apoptotic/necrotic cells were analyzed using FCS Express 5 (De Novo Software, Glendale, CA).

DNA Decatenation Assays. The inhibition of topoisomerase II $\alpha$ or II $\beta$ activity was measured using the ATP- and type II topoisomerase-dependent decatenation reaction of kinetoplast DNA (kDNA) catenanes to open and closed circular decatenated kDNA (Sahai and Kaplan, 1986). Methods were based on those of Hasinoff et al. (1997). Individual reactions took place in $10 \mu \mathrm{l}$ of $50 \mathrm{mM}$ Tris $\mathrm{HCl}$ (pH 8) buffer that contained $120 \mathrm{mM} \mathrm{KCl,} 10 \mathrm{mM} \mathrm{MgCl}_{2}, 0.5 \mathrm{mM}$ ATP, $0.5 \mathrm{mM}$ dithiothreitol, $30 \mu \mathrm{g} / \mathrm{ml}$ bovine serum albumin, 250-500 $\mathrm{ng}$ $\mathrm{kDNA}, 0.5 \mathrm{U}$ of purified topoisomerase II $\alpha$ or $20 \mathrm{ng} / \mathrm{ml}$ of purified topoisomerase II $\beta$ enzyme, and jadomycins B, S, and F (10-640 $\mu \mathrm{M})$, positive control DOX $(0.31-10 \mu \mathrm{M})$, or jadomycin vehicle. Reactions were incubated for 30 minutes at $37^{\circ} \mathrm{C}$ and stopped using $5 \times$ stop buffer containing $5 \%$ sarkosyl, $0.125 \%$ bromophenol blue, and $25 \%$ glycerol. The reaction products were separated by agarose gel $(1 \% \mathrm{w} / \mathrm{v})$ electrophoresis using TAE buffer. Both the agarose gel and the running TAE buffer contained $0.5 \mu \mathrm{g} / \mathrm{ml}$ ethidium bromide. Gels were run at $135 \mathrm{~V}$ for 15 minutes then destained in water for 10 minutes. Gels were photographed using an Olympus (Tokyo, Japan) C-4000 Zoom camera under UV transillumination. Decatenated kDNA (TopoGEN) was run as a control, along with kDNA untreated with topoisomerase II $\alpha$. The presence and brightness of the open circular and closed circular kDNA bands was used as a measure of topoisomerase II $\alpha$ or II $\beta$ activity, with the intensity of these bands measured using ImageJ. The intensity of these bands for each given treatment was compared with that of the jadomycin vehicle (labeled $0 \mu \mathrm{M})$, for which there was no topoisomerase inhibition, and relative topoisomerase II $\alpha$ or II $\beta$ inhibition was calculated.

DNA Cleavage Assays. The transient covalent complex that occurs between type II topoisomerases and DNA can be stabilized by topoisomerase II poisons (Liu, 1989), also known as interfacial inhibitors (Marchand and Pommier, 2012), and the presence of these poison-DNAtopoisomerase complexes can be measured by quantifying the formation of linear DNA cleavage products from supercoiled plasmid DNA (Burden et al., 2001). The following protocol is based on that of Burden et al. (2001) with minor alterations. Individual reactions were conducted in $20 \mu \mathrm{l}$ of $10 \mathrm{mM}$ Tris $\mathrm{HCl}$ ( $\mathrm{pH} 7.9$ ) buffer that contained $100 \mathrm{mM} \mathrm{KCl}$, $0.1 \mathrm{mM}$ Na-EDTA, $5 \mathrm{mM} \mathrm{MgCl}_{2}, 2.5 \%$ glycerol, $250 \mathrm{ng}$ pHOT1 DNA, $8 \mathrm{U}$ of purified topoisomerase II $\alpha$ or $50 \mu \mathrm{g} / \mathrm{ml}$ purified topoisomerase II $\beta$, and jadomycins $\mathrm{B}, \mathrm{S}$, and $\mathrm{F}(10-640 \mu \mathrm{M})$, positive control etoposide $(100 \mu \mathrm{M})$, or jadomycin vehicle. Reactions were incubated for 6 minutes at $37^{\circ} \mathrm{C}$ and stopped by adding $2 \mu \mathrm{l}$ of $5 \%$ SDS, followed by treatment with $1 \mu \mathrm{l}$ of $375 \mathrm{mM}$ Na-EDTA and $2 \mu \mathrm{l}$ of $0.8 \mathrm{mg} / \mathrm{ml}$ proteinase $\mathrm{K}$, respectively. Reactions were further incubated for 30 minutes at $45^{\circ} \mathrm{C}$ and then treated with $2 \mu \mathrm{l}$ of loading dye $[0.6 \mathrm{~g} / \mathrm{ml}$ sucrose, $10 \mathrm{mM}$ Tris $\mathrm{HCl}$ (pH 7.9), and $2.5 \mathrm{mg} / \mathrm{ml}$ bromophenol blue]. The reaction products were separated by agarose gel $(1 \% \mathrm{w} / \mathrm{v})$ electrophoresis in TAE buffer that contained $0.5 \mu \mathrm{g} / \mathrm{ml}$ ethidium bromide. Gels were run at $100 \mathrm{~V}$ for $\sim 30$ minutes, destained in water for 15 minutes, and photographed using an Olympus C-4000 Zoom camera under UV transillumination. The formation of linear pHOT1 DNA normalized to the remaining supercoiled DNA was used as a measure of topoisomerase II $\alpha$ or II $\beta$ poisoning for each given drug treatment, with the intensity of these bands measured using ImageJ. The normalized intensity of each band was then compared with that of the jadomycin vehicle (labeled $0 \mu \mathrm{M}$ ) to calculate the relative topoisomerase $\mathrm{II} \alpha$ or $\mathrm{II} \beta$ poisoning.

Statistical Analysis. All data are presented as the mean value of at least three separate replicated trials with the values of each trial displayed in scatter plots. An unpaired $t$ test was performed for dual comparisons in experiments with one independent variable. A oneway or two-way analysis of variance (ANOVA) was performed for multiple comparisons in experiments with one or two independent variables, respectively. A Bonferroni multiple-comparison test was used for post hoc analysis of the significant ANOVA. A difference between mean values between groups was considered significant at $P \leq 0.05$.

\section{Results}

231-TXL Cells Overexpress $A B C B 1$ and Jadomycins Are Equipotent in 231-TXL versus 231-CON Cells. A 95,000-fold increase in the mRNA level of $A B C B 1$ was observed in the 231-TXL versus 231-CON cells, although no difference was seen in the expression of $A B C C 1$ or $A B C G 2$ (Fig. 2a). Using MTT assays, the $\mathrm{IC}_{50}$ values of jadomycins $\mathrm{B}$, $\mathrm{S}$, and $\mathrm{F}$ were determined to be equal in both the drugsensitive 231-CON and MDR 231-TXL breast cancer cells, whereas the $\mathrm{IC}_{50}$ values of the ABCB1 substrates mitoxantrone and DOX were significantly higher in the 231-TXL versus 231-CON cells (Fig. 2b).

Jadomycins Induce Intracellular ROS Activity in 231-CON and 231-TXL Cells, Which Can Be Altered Using Antioxidant or Pro-Oxidant Cotreatments. Jadomycins $\mathrm{B}(40 \mu \mathrm{M}), \mathrm{S}(30$ and $40 \mu \mathrm{M})$, and $\mathrm{F}(40 \mu \mathrm{M})$ significantly increased 

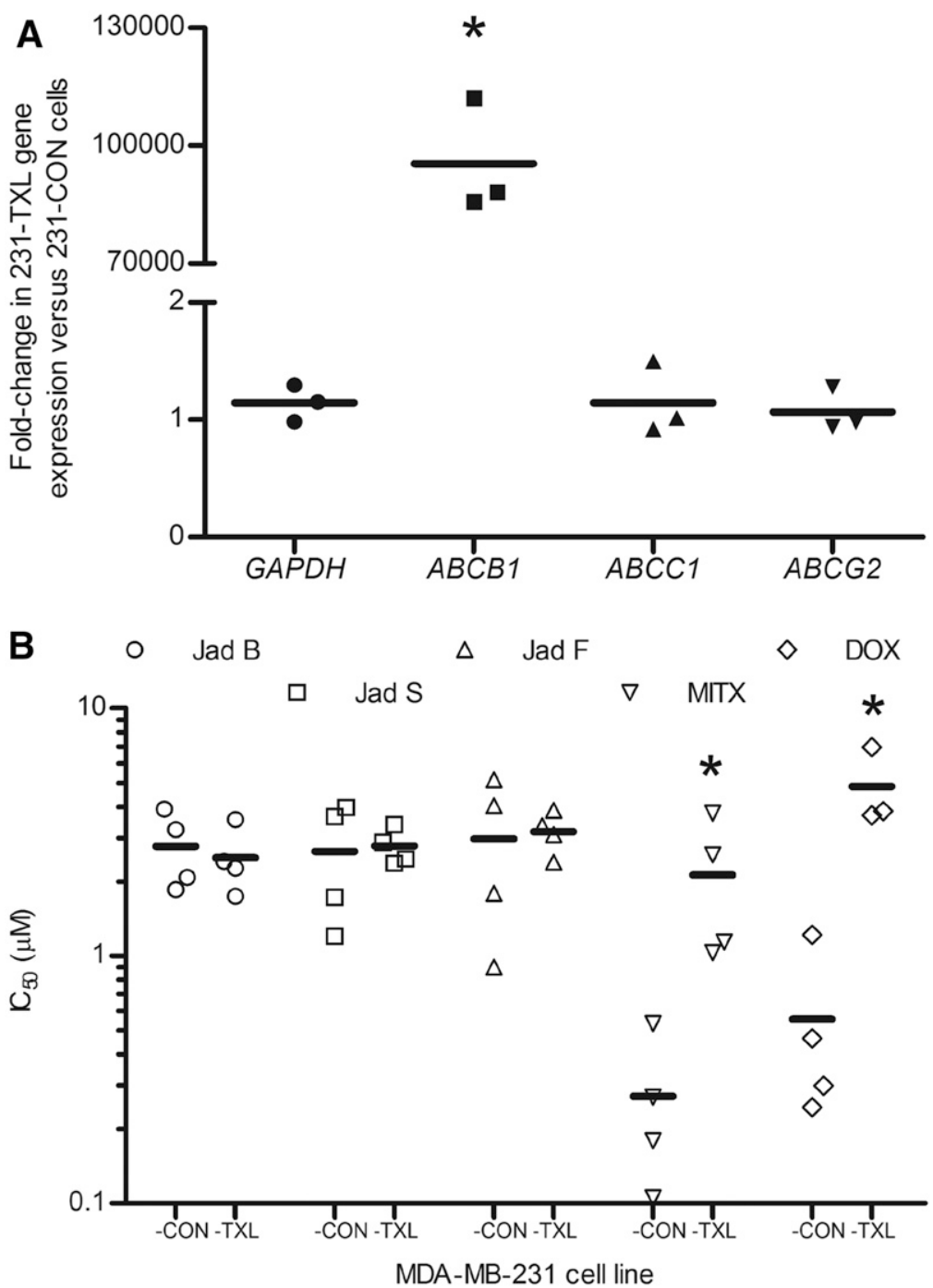

Fig. 2. (a) Growth of MDA-MB-231 cells in TXL selection medium for 7 months generated the MDR breast cancer cell line 231-TXL that specifically overexpressed $A B C B 1$ vs. drugsensitive 231-CON cells, as measured using quantitative PCR. (b) The $\mathrm{IC}_{50}$ values of jadomycins (Jads) B, S, and F (72-hour treatments) in MTT assays were equal in 231-TXL cells vs. 231CON cells. The $\mathrm{IC}_{50}$ values of the control drugs mitoxantrone (MITX) and DOX were significantly higher in the 231-TXL cells vs. 231-CON cells. Each bar represents the mean of at least three independent experiments. $* P \leq 0.05$, the indicated expression of the gene was significantly different from that of the GAPDH housekeeping control as determined by a one-way ANOVA followed by Bonferroni multiple-comparison test (a), or the average $\mathrm{IC}_{50}$ value of the indicated drug treatment in 231-TXL cells was significantly different from that measured in the 231-CON cells as determined by an unpaired $t$ test (b).
ROS in 231-CON cells in comparison with the jadomycin vehicle (Fig. 3a). This ROS activity increases linearly with time up to 24 hours (Supplemental Fig. 1). The antioxidant and glutathione precursor NAC and the pro-oxidant and thioredoxin reductase inhibitor auranofin were used to inhibit or enhance ROS levels in the cells after jadomycin treatments (Hall et al., 2015). NAC (2.5 mM) and auranofin $(1 \mu \mathrm{M})$ significantly decreased and increased, respectively, ROS activity in the 231-CON cells when cotreated with jadomycins $\mathrm{S}$ or $\mathrm{F}(40 \mu \mathrm{M})$, though not when cotreated with jadomycin $\mathrm{B}(40 \mu \mathrm{M})$ (Fig. 3b). Since all jadomycins induced ROS, jadomycin $\mathrm{S}$ was chosen as a representative jadomycin for this and all of the following replicative experiments involving 231-TXL cells. Jadomycin S was chosen due to greater water solubility and biosynthetic yields versus jadomycins B and F. Jadomycin $\mathrm{S}(20$ and $40 \mu \mathrm{M})$ significantly increased ROS activity in the 231-TXL cells, and, although NAC significantly decreased jadomycin $\mathrm{S}(40 \mu \mathrm{M})$-induced ROS activity, auranofin had no effect (Fig. 3c).

Jadomycins Induce DNA Double-Strand Breaks in 231-CON and 231-TXL Cells. When double-strand breaks occur within DNA, it is always followed by the phosphorylation of histone $\mathrm{H} 2 \mathrm{AX}$; the amount of phosphorylated histone $\mathrm{H} 2 \mathrm{AX}(\gamma \mathrm{H} 2 \mathrm{AX})$ in cells treated with cytotoxic agents can therefore be used as a measure of DNA double-strand breaks
(Kuo and Yang, 2008). In 231-CON cells, jadomycins B, S, and $\mathrm{F}(15 \mu \mathrm{M})$ and the control mitoxantrone $(1 \mu \mathrm{M})$ significantly increased $\gamma \mathrm{H} 2 \mathrm{AX}$ protein levels versus the vehicle control, as measured using Western blotting (Fig. 4a). Jadomycin S $(15 \mu \mathrm{M})$ significantly increased $\gamma \mathrm{H} 2 \mathrm{AX}$ protein expression in 231-TXL cells, whereas mitoxantrone did not (Fig. 4b). The induction of $\gamma \mathrm{H} 2 \mathrm{AX}$ protein expression in 231-CON cells by jadomycin $\mathrm{S}(15 \mu \mathrm{M})$ was not altered by cotreatment with the antioxidant NAC $(2.5 \mathrm{mM})$ or pro-oxidant auranofin $(1 \mu \mathrm{M})$, whereas cotreatment with benzamide $(100 \mu \mathrm{M})$, an inhibitor of DNA repair poly(ADP-ribose) polymerases (PARPs) (Steffen et al., 2011), significantly increased $\gamma \mathrm{H} 2 \mathrm{AX}$ protein expression. None of the cotreatments affected $\gamma \mathrm{H} 2 \mathrm{AX}$ levels on their own (Fig. 4c).

Jadomycins Induce Apoptosis in 231-CON and 231TXL Cells. Apoptosis induced by cytotoxic drugs can be measured using annexin $\mathrm{V}$ affinity assays, which differentiate healthy, early apoptotic, and dead (also labeled late apoptotic/necrotic) cells using fluorescently labeled annexin $\mathrm{V}$ and propidium iodide followed by fluorescence-activated cell sorter (FACS) analysis (van Engeland et al., 1998; Greenshields et al., 2015). Two examples of annexin $\mathrm{V}$ affinity assays can be seen in Fig. 5a, depicting 231-CON cells treated with either 

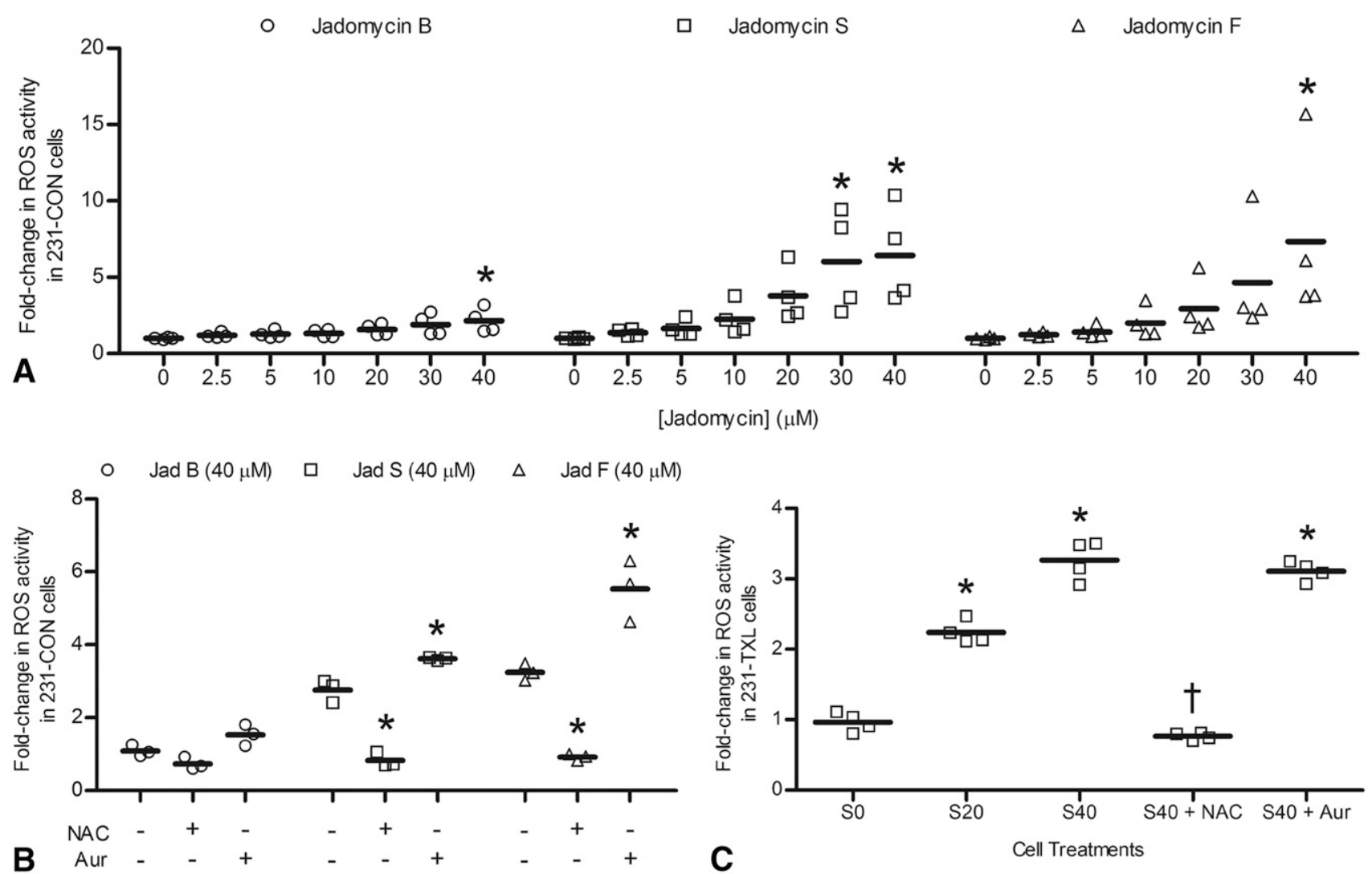

Fig. 3. (a) Jadomycins (Jads) B, S, and F (2.5-40 $\mu \mathrm{M}$ ) concentration-dependently increased ROS activity in 231-CON cells. (b) The antioxidant NAC $(2.5 \mathrm{mM}$ ) decreased and the pro-oxidant auranofin (Aur; $1 \mu \mathrm{M}$ ) increased intracellular ROS activity in Jad S and F treated 231-CON cells. (c) Jad $\mathrm{S}$ $(20-40 \mu \mathrm{M})$ concentration-dependently increased ROS activity in 231-TXL cells. NAC significantly decreased ROS activity induced by Jad S (40 $\mu \mathrm{M})$ in 231-TXL cells, whereas Aur had no effect. ROS activity was expressed as a fold change relative to the medium-treated control cells. Each bar represents the mean of at least three independent experiments. ${ }^{*} P \leq 0.05$, the fold change in ROS activity was significantly different compared with the vehicle control ( $0 \mu \mathrm{M}$ or S0) (a and c) or compared with the no-cotreatment control for that specific jadomycin (b); and $\dagger P<0.05$ compared with the S40 treatment (c) as determined by one-way ANOVAs, followed by Bonferroni multiple-comparison tests.

the vehicle control (left-hand side) or jadomycin $\mathrm{S}(20 \mu \mathrm{M}$; right-hand side) for 36 hours. Healthy cells are in the bottom left quadrant (no fluorescence), early apoptotic is in the bottom right quadrant (annexin V fluorescence), and late apoptotic/necrotic cells are in the top right quadrant (annexin $\mathrm{V}$ and propidium iodide fluorescence).

Thirty-six hour treatments with jadomycins $\mathrm{B}$ and $\mathrm{F}$ $(20 \mu \mathrm{M})$, jadomycin $\mathrm{S}(10$ and $20 \mu \mathrm{M})$, and the control mitoxantrone $(1 \mu \mathrm{M})$ induced significantly more early apoptosis versus the vehicle control (labeled $0 \mu \mathrm{M}$ ) in the 231-CON cells (Fig. 5b). As well, these 36-hour jadomycin B, S (10 and $20 \mu \mathrm{M}$ ), and $\mathrm{F}$ (5 and $20 \mu \mathrm{M}$ ), and mitoxantrone $(0.1 \mu \mathrm{M})$ treatments significantly increased the number of late apoptotic/ necrotic cells versus the vehicle control treatments (Fig. 5c). In the 231-TXL cells, jadomycin $\mathrm{S}(20 \mu \mathrm{M})$ and mitoxantrone $(1 \mu \mathrm{M})$ induced significantly greater early apoptosis versus the vehicle control (Fig. 5d), although only jadomycin $\mathrm{S}$ induced significantly more late apoptosis/necrosis (Fig. 5e).

Jadomycin Cytotoxicity Is Enhanced by Auranofin and Benzamide and Reduced by Z-VAD. Jadomycins B $(30 \mu \mathrm{M}), \mathrm{S}(20 \mu \mathrm{M})$, and $\mathrm{F}(30 \mu \mathrm{M})$ and mitoxantrone $(1 \mu \mathrm{M})$ induced equal amounts of early apoptosis and late apoptosis/necrosis with or without cotreatment with antioxidant NAC $(2.5 \mathrm{mM})$ after 36 hours (Fig. 6a). The pro-oxidant auranofin $(1 \mu \mathrm{M})$ had no effect on the amount of early apoptosis induced by jadomycins $\mathrm{B}$, S, or F ( $5 \mu \mathrm{M})$; however, it did significantly increase the number of late apoptotic/necrotic cells. Auranofin did not affect the cytotoxicity of mitoxantrone $(0.1 \mu \mathrm{M})$ (Fig. $6 \mathrm{~b})$. The PARP inhibitor benzamide $(5 \mathrm{mM})$, although having no effect on late apoptosis/necrosis when cotreated with any of the jadomycins $(5 \mu \mathrm{M})$ or mitoxantrone $(0.1 \mu \mathrm{M})$, did significantly increase the amount of early apoptosis induced by jadomycin $\mathrm{S}$ after a 48-hour treatment (Fig. 6c). The cell-permeable, irreversible pan-caspase inhibitor Z-VAD $(100 \mu \mathrm{M})$ (Cohen, 1997) had no effect on late apoptosis/ necrosis, although it did significantly reduce the number of early apoptotic cells when cotreated with jadomycins B $(30 \mu \mathrm{M})$, $\mathrm{S}(20 \mu \mathrm{M})$, and $\mathrm{F}(30 \mu \mathrm{M})$ or mitoxantrone $(1 \mu \mathrm{M})$ for 36 hours (Fig. 6d). After 36-hour cotreatments in the 231-TXL cells, Z-VAD significantly decreased jadomycin $\mathrm{S}(20 \mu \mathrm{M})$-induced early apoptosis, whereas NAC, auranofin, and benzamide had no effect. Auranofin and benzamide both significantly increased the amount of late apoptosis/necrosis measured in the 231-TXL cells when cotreated with jadomycin S, although NAC and Z-VAD had no noticeable effect. No significant differences in early apoptosis or late apoptosis/necrosis were observed with any of the cotreatments when used with mitoxantrone $(1 \mu \mathrm{M})$ (Fig. 6e). None of these cotreatments had any effect on cell death on their own at the concentrations indicated.

Jadomycins Are Type II Topoisomerase Inhibitors. The lack of effect of NAC and auranofin on jadomycin-induced 

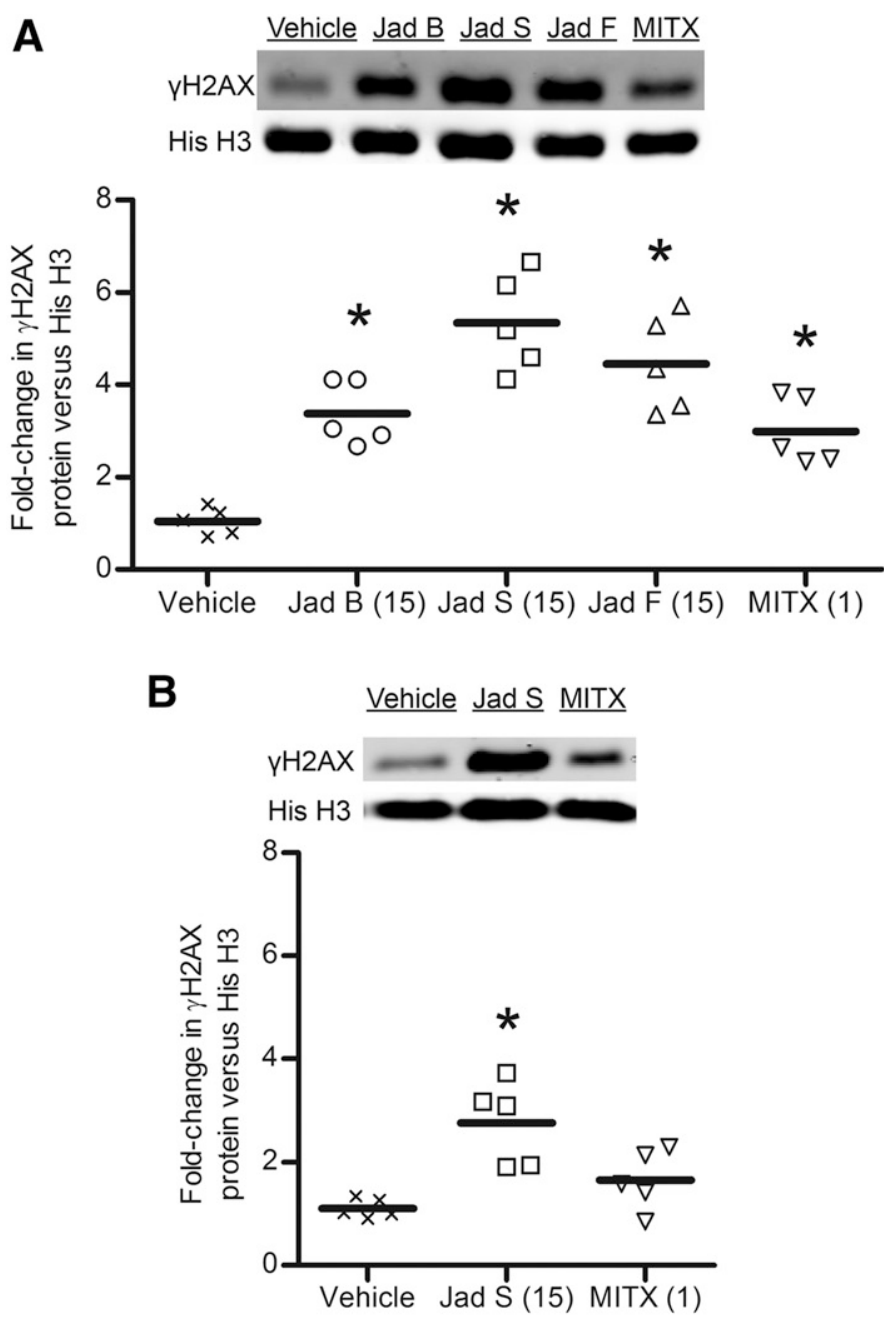

C Vehicle NAC Aur Benz Jad S $\underline{\underline{\mathrm{Jad} S}} \underline{\mathrm{Jad} S} \underline{\mathrm{Jad} S}$
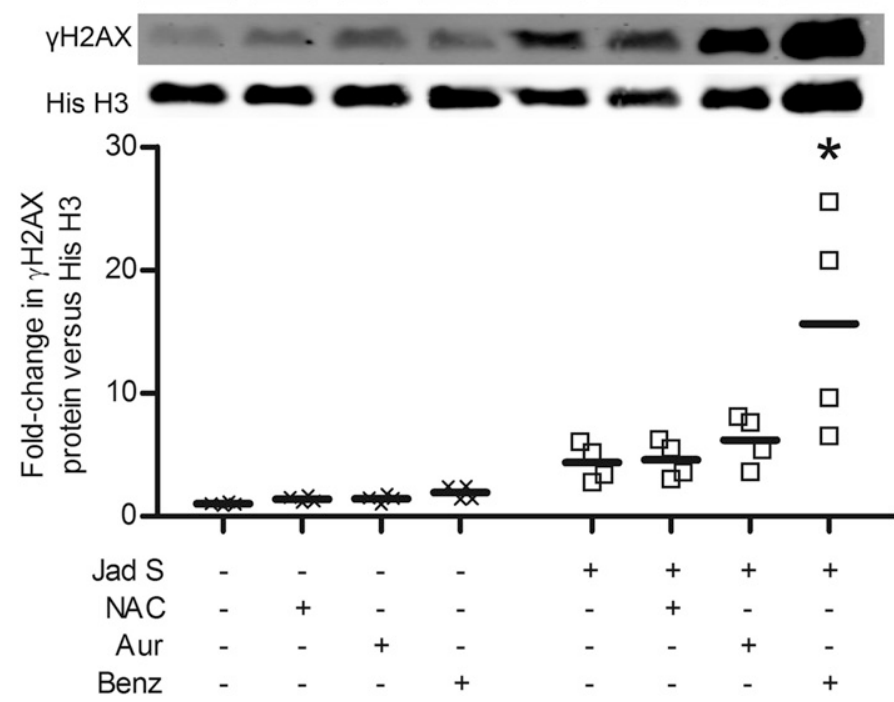

Fig. 4. (a) Jadomycins (Jads) B, S, and F (15 $\mu \mathrm{M}, 24$-hour treatment) and mitoxantrone (MITX; $1 \mu \mathrm{M}$ ) increased the phosphorylation of histone $\mathrm{H} 2 \mathrm{AX}(\gamma \mathrm{H} 2 \mathrm{AX}$; a marker of double-strand DNA breaks) vs. vehicle control in 231-CON cells. (b) In 231-TXL cells, Jad S (15 $\mu \mathrm{M}$, 24-hour treatment) but not MITX $(1 \mu \mathrm{M})$ increased $\gamma \mathrm{H} 2 \mathrm{AX}$ protein expression vs. vehicle control. (c) The PARP inhibitor benzamide (Benz; $5 \mathrm{mM}$ ), but not NAC $(2.5 \mathrm{mM})$ or auranofin (Aur; $1 \mu \mathrm{M})$, further increased $\gamma \mathrm{H} 2 \mathrm{AX}$ in Jad
DNA damage and early apoptosis suggested a ROS-independent mechanism. Martinez-Farina et al. (2015) recently determined that the jadomycin analog DS bonds to human topoisomerase II $\beta$ protein, and a preliminary cancer gene target array we completed in MCF7 cells showed decreased expression of topoisomerase genes when treated with $10 \mu \mathrm{M}$ jadomycin $\mathrm{S}$ (data not shown). Therefore, we chose to probe the possible involvement of topoisomerase inhibition by jadomycins as a ROS-independent mechanism of DNA damage and apoptosis.

Jadomycins $\mathrm{B}, \mathrm{S}$, and $\mathrm{F}(20 \mu \mathrm{M}, 36$-hour treatments) significantly reduced the expression of $T O P 2 A$ and $T O P 2 B$, the genes that encode for topoisomerases II $\alpha$ and II $\beta$, respectively, in 231-CON cells versus the vehicle control (Fig. 7a). A smaller but statistically significant decrease in TOP1, the gene that encodes topoisomerase I, was observed for jadomycin $\mathrm{S}$ with no significant changes for jadomycins B or $\mathrm{F}$. The mitoxantrone control had no effect on TOP1 expression, although it did cause a small TOP2A increase and TOP2B decrease versus the vehicle. Jadomycin $\mathrm{S}(20 \mu \mathrm{M}, 36$-hour treatment) caused similar significant decreases in TOP1, TOP2A, and TOP2B expression in the 231-TXL cells, although mitoxantrone had no effect (Fig. 7b). The PCR primers used are listed in Table 1.

Jadomycins B, S, and F (15 $\mu \mathrm{M}, 24$-hour treatments) and mitoxantrone ( $1 \mu \mathrm{M}, 24$-hour treatment) significantly lowered the levels of topoisomerase II $\alpha$ protein versus the vehicle control (Fig. 7c). Jadomycin S (15 $\mu \mathrm{M}, 24$-hour treatment) but not mitoxantrone ( $1 \mu \mathrm{M}, 24$-hour treatment) decreased topoisomerase II $\alpha$ in the 231-TXL cells (Fig. 7d).

Using a protocol adapted from Topogen and Hasinoff et al. (1997), the ability of jadomycins and the known topoisomerase poison DOX to directly inhibit topoisomerases II $\alpha$ and II $\beta$ was measured. Jadomycins B, S, and F (10-640 $\mu \mathrm{M})$ and DOX $(0.3125-10 \mu \mathrm{M})$ all concentration-dependently and directly inhibited both topoisomerase isoforms (Fig. 8). The topoisomerase II $\alpha \mathrm{IC}_{50}$ values of jadomycins $\mathrm{S}$ and $\mathrm{F}$ and DOX were significantly lower than that of jadomycin B, and the topoisomerase $\mathrm{II} \beta \mathrm{IC}_{50}$ value for $\mathrm{DOX}$ was lower than that of jadomycin B. No drug was differentially potent in its inhibition of topoisomerase II $\alpha$ versus II $\beta$ (Table 2 ).

DNA cleavage assays were completed to determine whether jadomycins are type II topoisomerase poisons or catalytic inhibitors (Burden et al., 2001). The positive control etoposide (Hasinoff et al., 2016) increased the amount of DNA cleavage induced by topoisomerases II $\alpha$ and II $\beta$ at $100 \mu \mathrm{M}$, whereas jadomycins B and F selectively increased DNA cleavage induced by topoisomerase II $\beta$ at 640 and $320 \mu \mathrm{M}$, respectively, with no effect on topoisomerase II $\alpha$. Jadomycin S did not affect either topoisomerase isoform at any concentration used (Fig. 9). Bands representing nicked open circular plasmid DNA in the agarose gels, which can be used to quantify topoisomerase II-generated single-strand

S-treated (15 $\mu \mathrm{M}, 24$-hour treatment) 231-CON cells. When administered as single treatments, NAC, Aur, and Benz did not affect $\gamma \mathrm{H} 2 \mathrm{AX}$ levels. $\gamma \mathrm{H} 2 \mathrm{AX}$ protein expression was depicted as a fold change relative to the medium-treated control cells. Each bar represents the mean of at least four independent experiments. ${ }^{*} P \leq 0.05$, the fold change in $\gamma \mathrm{H} 2 \mathrm{AX}$ protein expression was significantly different when compared with the vehicle ( $\mathrm{a}$ and $\mathrm{b}$ ) or when compared with $15 \mu \mathrm{M}$ Jad $\mathrm{S}$ alone, as determined by one-way ANOVAs, followed by Bonferroni multiple-comparison tests (c). 
Vehicle

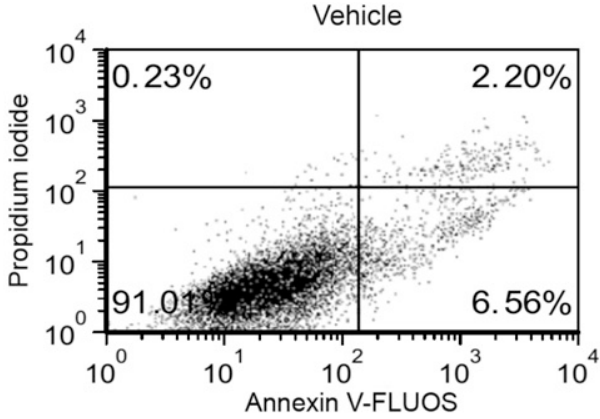

○ Jadomycin B

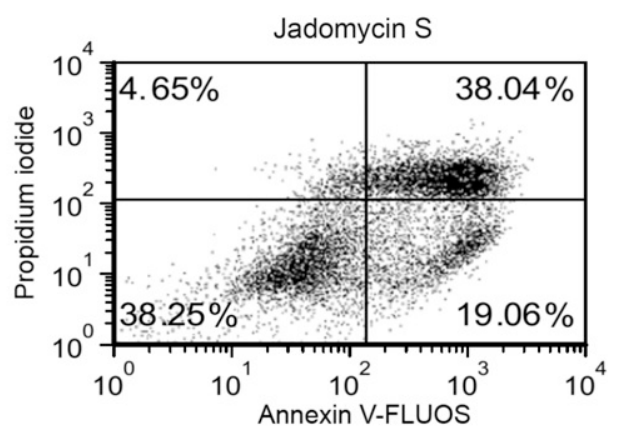

$\Delta \quad$ Jadomycin $\mathrm{F}$ $\nabla \quad$ Mitoxantrone
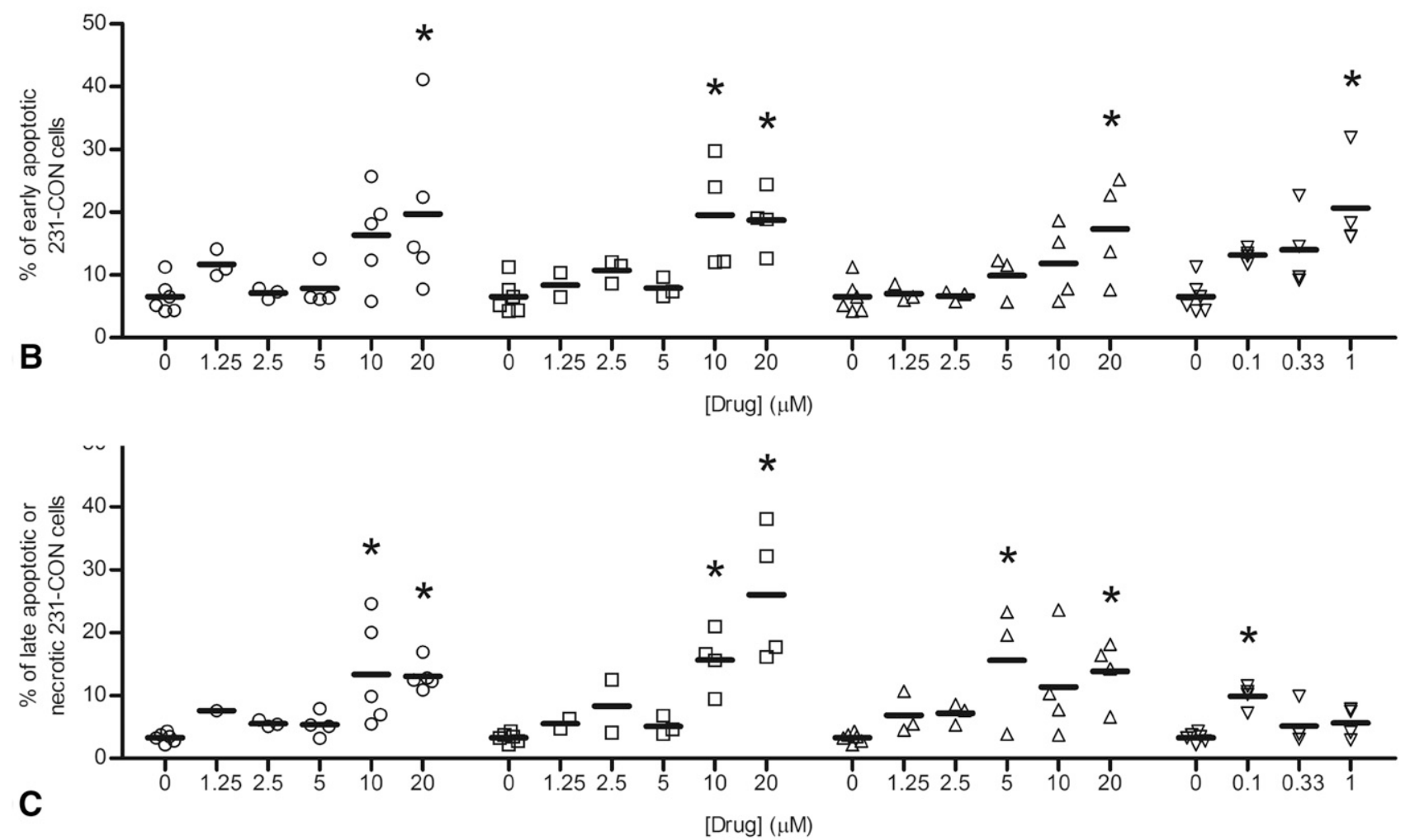

[Drug] $(\mu \mathrm{M})$
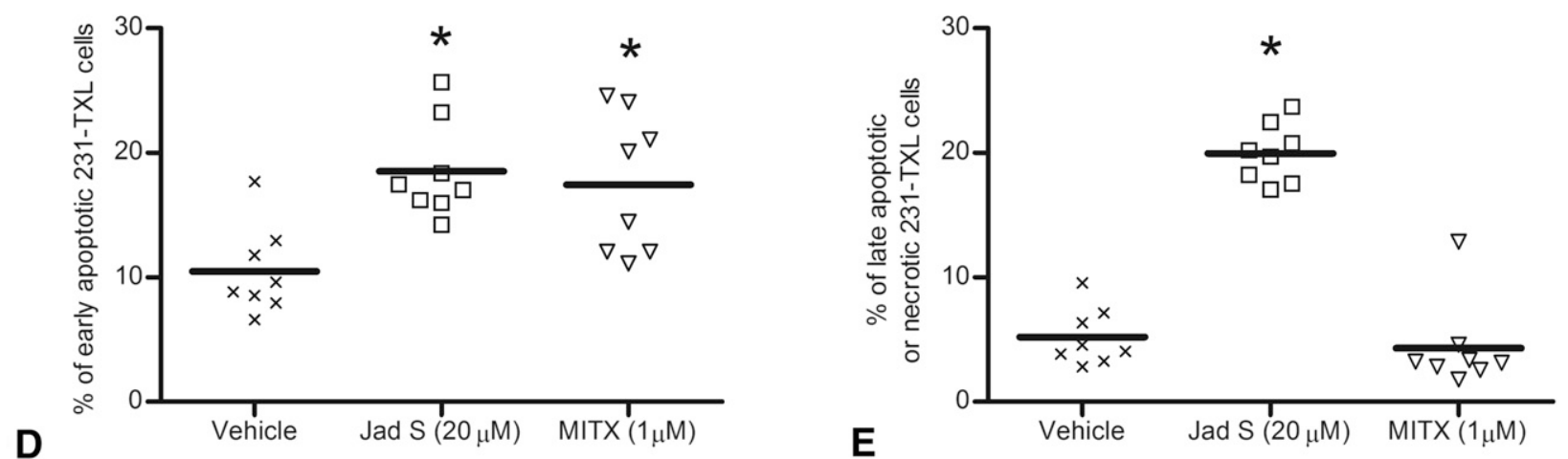

Fig. 5. (a) Right-hand side representative FACS figure shows how jadomycin (Jad) $\mathrm{S}(20 \mu \mathrm{M}$; 36-hour treatment) induced more 231 -CON cell death than jadomycin vehicle on the left-hand side. Bottom left-hand side quadrants show the percentage of healthy cells, bottom right-hand side quadrants show early apoptotic cells, and top right-hand side quadrant shows late apoptotic/necrotic cells. Jadomycins B, S, or F (1.25-20 $\mu \mathrm{M})$ or mitoxantrone (MITX) $(0.1-1 \mu \mathrm{M})$ treatments for 36 hour induced significantly greater early apoptosis (b) and late apoptosis/necrosis (c) vs. vehicle (labeled $0 \mu \mathrm{M})$ in drugsensitive 231-CON cells. Jad S $(20 \mu \mathrm{M})$ and MITX $(1 \mu \mathrm{M})$ significantly increased early apoptosis in MDR 231-TXL cells vs. the vehicle control after 36-hour treatments (d), and Jad S also increased late apoptosis/necrosis (e). Each bar represents the mean of at least three independent experiments. ${ }^{*} P \leq 0.05$, the percentage of early apoptosis or the percentage of late apoptosis/necrosis was significantly different compared with the vehicle treatment controls, as determined by one-way ANOVAs, followed by Bonferroni multiple-comparison tests. 

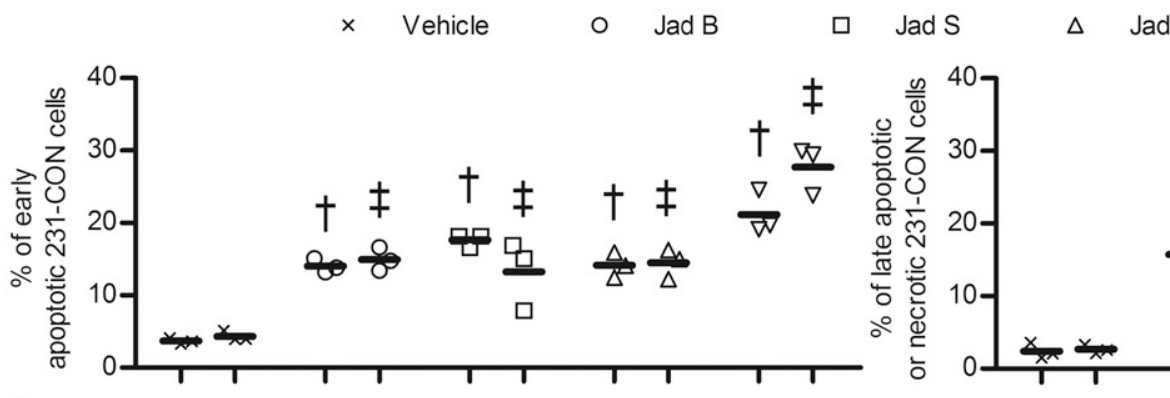

F $\quad \nabla \quad$ MTX

A
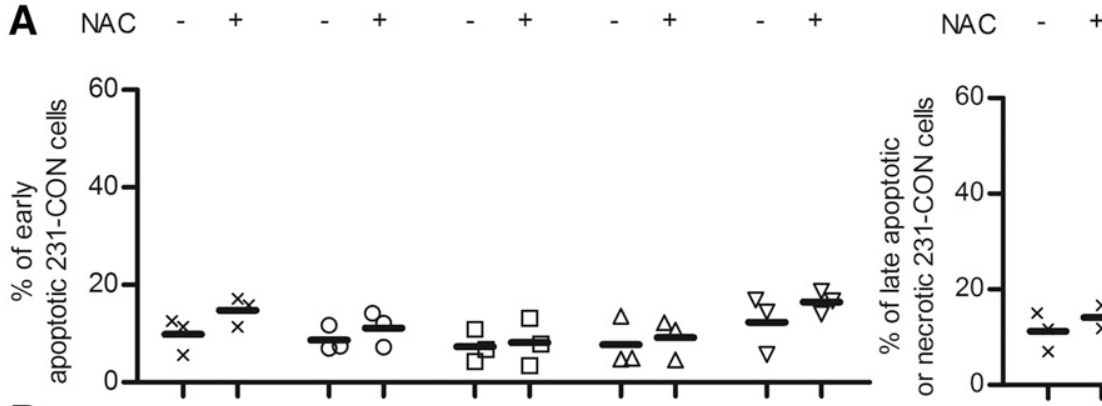

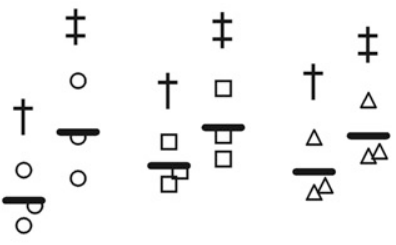

B
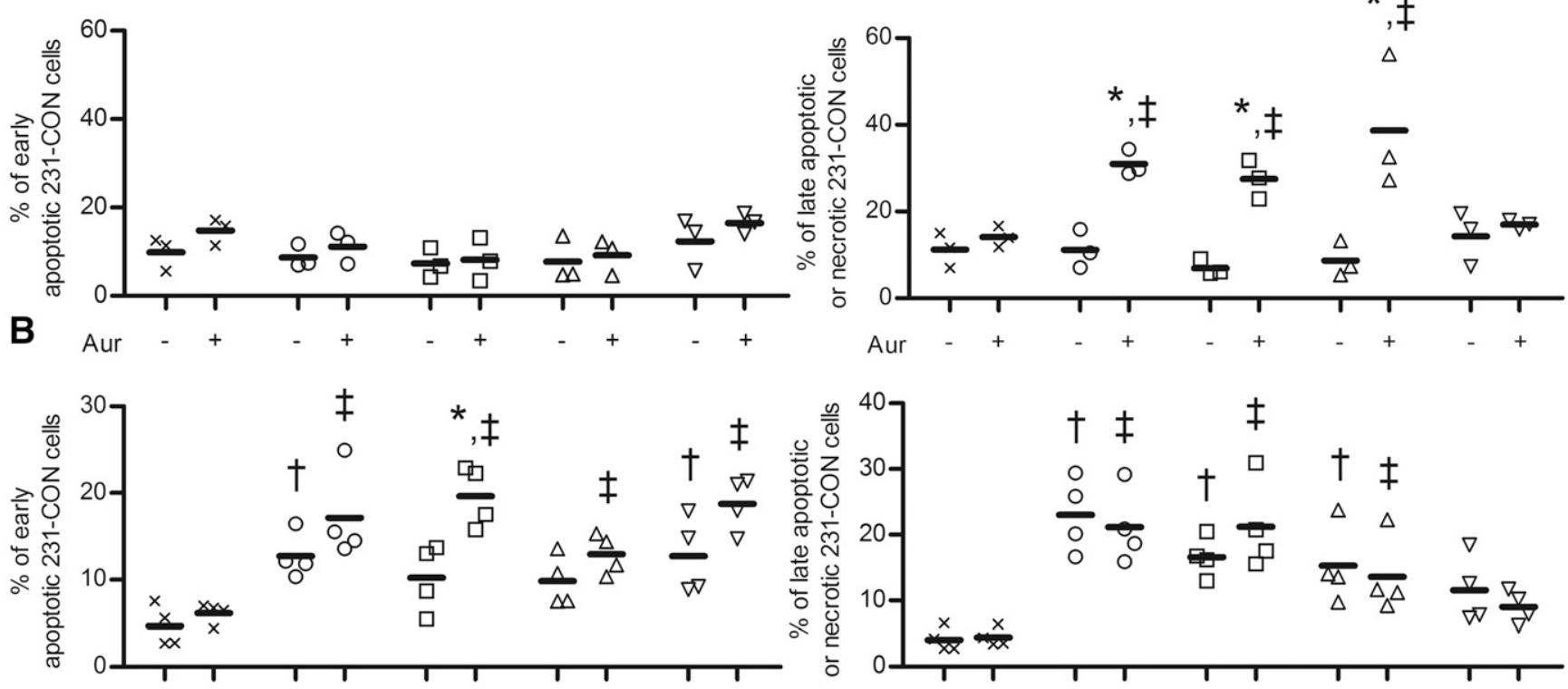

C Benz

Benz
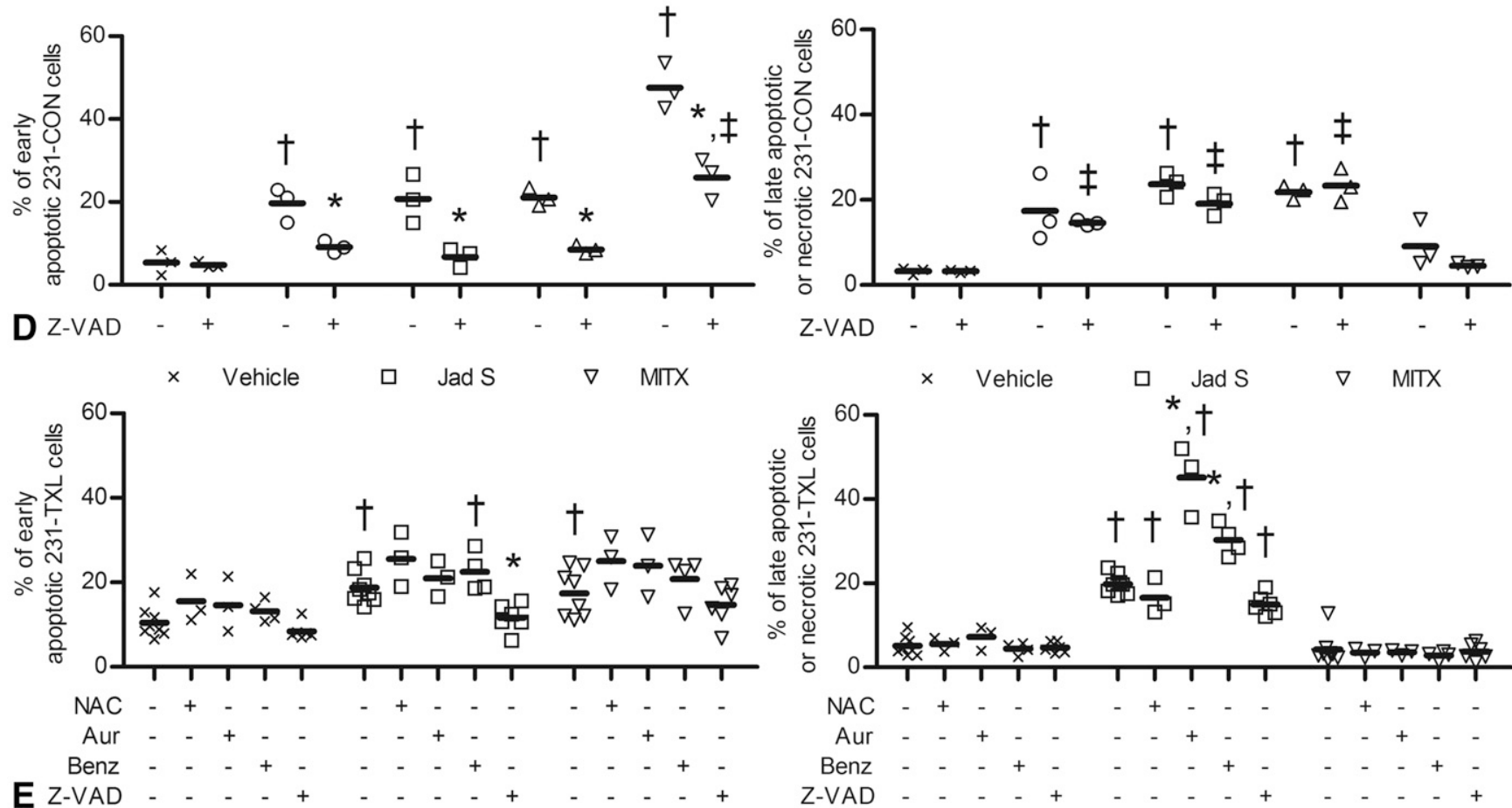

Fig. 6. (a) NAC (2.5 mM) did not affect jadomycin (Jad) B-, S-, or F-induced (30, 20, and $30 \mu \mathrm{M}$, respectively) or mitoxantrone (MITX; $1 \mu \mathrm{M})$-induced early apoptosis or late apoptosis/necrosis after 36-hour treatment in 231-CON cells. (b) Auranofin (Aur; $1 \mu \mathrm{M}$ ) did not affect early apoptosis with Jads B, $\mathrm{S}$, or F $(5 \mu \mathrm{M})$ or MITX $(0.1 \mu \mathrm{M})$ after 24 hours in 231-CON cells. It did increase late apoptosis/necrosis when cotreated with each Jad, though not with MITX. (c) Benzamide (Benz; $5 \mathrm{mM}$ ) increased early apoptosis induced by Jad S (5 $\mu \mathrm{M})$ after 48 hours in 231-CON cells, with no effect on late 

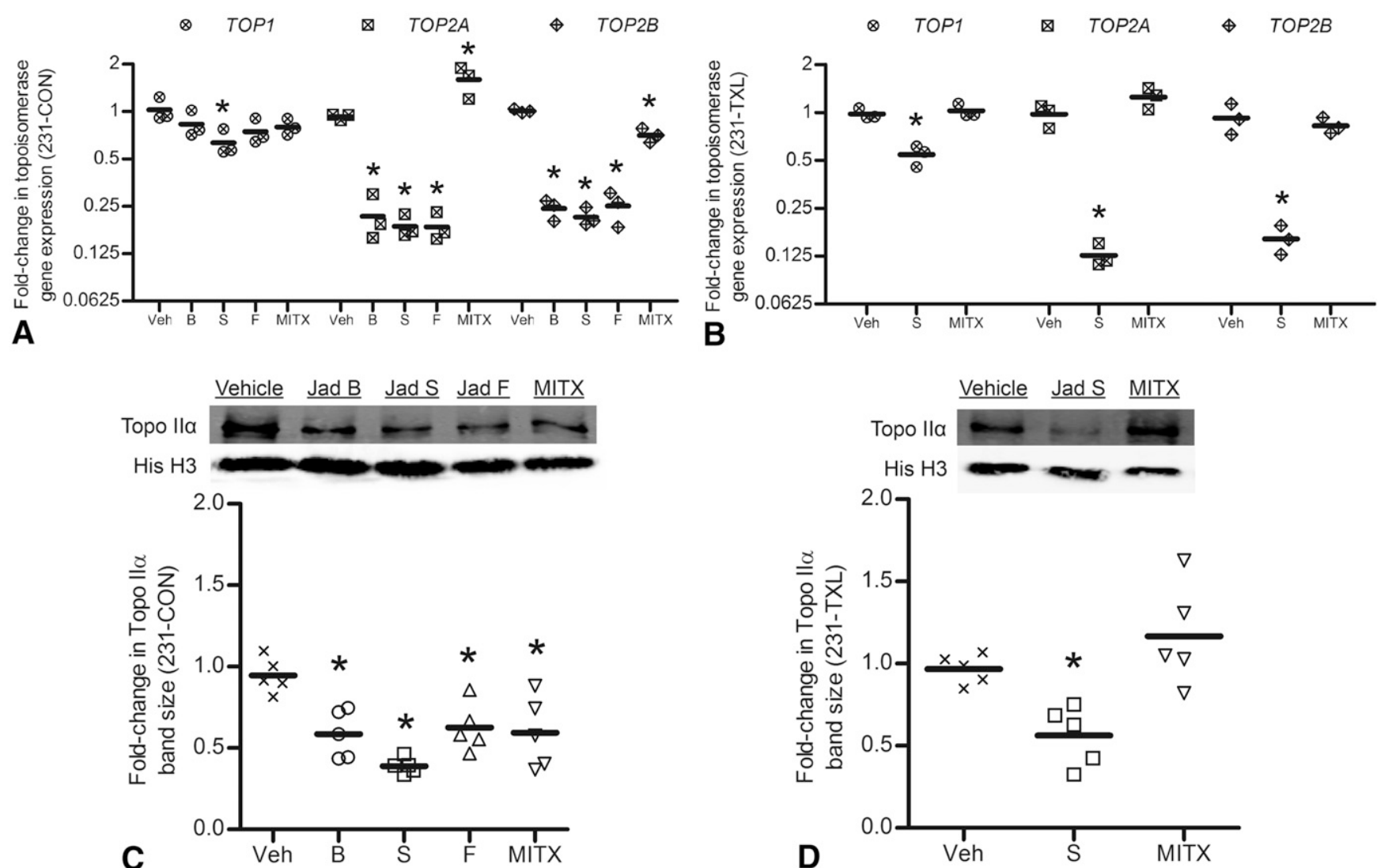

Fig. 7. (a) Jadomycins (Jads) B, S, and $\mathrm{F}(20 \mu \mathrm{M})$ all significantly reduced the expression of TOP2A and TOP2B genes in $231-\mathrm{CON}$ cells after 36 hours. A small TOP1 decrease was also observed with Jad S. The mitoxantrone (MITX) control ( $1 \mu \mathrm{M})$ did not alter TOP1, though it did increase TOP2A and decrease TOP $2 B$ expression. (b) Jad S $(20 \mu \mathrm{M})$ significantly decreased TOP1, TOP2A, and TOP2B expression in 231-TXL cells after 36 hours. MITX $(1 \mu \mathrm{M})$ had no effect. (c) Jads B, S, and $\mathrm{F}(15 \mu \mathrm{M})$ and MITX $(1 \mu \mathrm{M})$ significantly lowered the histone H3 normalized topoisomerase (Topo) II $\alpha$ protein expression after 24 hours in 231-CON cells relative to the vehicle control (Veh). (d) Jad S (15 $\mu \mathrm{M}$, 24-hour treatment) significantly lowered the amount of topoisomerase II $\alpha$ protein detected, whereas MITX $(1 \mu \mathrm{M})$ did not after 24 hours in 231-TXL cells. Each bar represents the mean of at least three independent experiments. ${ }^{*} P \leq 0.05$, the value is significantly different from the Veh as determined by a one-way ANOVA, followed by Bonferroni multiple-comparison test.

DNA breaks (Bandele and Osheroff, 2009), were not visible or were too dim to be quantified, and were therefore not included in the analysis.

\section{Discussion}

By exposing triple-negative MDA-MB-231 breast cancer cells to gradually increasing concentrations of TXL, we successfully created a polyclonal MDR cell line that overexpressed $A B C B 1$ and was resistant to the ABCB1 substrates mitoxantrone and DOX (Consoli et al., 1997; Shen et al., 2008), but not to jadomycins. This corroborates our earlier results describing how jadomycin potency is largely unaffected by
ABC transporter overexpression in MCF7 cells (Issa et al., 2014), providing further evidence of the potential of jadomycins in ABC transporter overexpressing MDR cancers.

We verified that jadomycins retained their ROS-inducing properties in 231-CON and 231-TXL triple-negative breast cancer cells, as previously observed in hormone receptor-positive MCF7 cells (Hall et al., 2015), evidencing that jadomycin ROS induction is independent of hormone receptor expression. Although the antioxidant effects of NAC (Dodd et al., 2008) were retained in jadomycin-treated resistant 231-TXL cells, the prooxidant effects of auranofin (Liu et al., 2013) were not, suggesting that these cells developed resistance to the ROS-inducing properties of auranofin.

apoptosis/necrosis. It had no significant effect with Jads B and F (5 $\mu \mathrm{M})$ or MITX $(0.1 \mu \mathrm{M})$. (d) Z-VAD (100 $\mu \mathrm{M})$ significantly reduced early apoptosis induced by Jads B, S, and F and MITX (30, 20,30, and $1 \mu \mathrm{M}$, respectively) after 36 hours in 231-CON cells, while having no effect on late apoptosis/necrosis. (e) Z-VAD (100 $\mu \mathrm{M})$ significantly decreased and NAC (2.5 mM), Aur $(1 \mu \mathrm{M})$, and Benz (5 mM) did not affect early apoptosis when cotreated with Jad S $(20 \mu \mathrm{M})$ in 231-TXL cells for 36 hours. Aur and Benz increased Jad S-induced late apoptosis/necrosis, whereas NAC and Z-VAD had no effect. None of the cotreatments affected early apoptosis or late apoptosis/necrosis levels induced by MITX ( $1 \mu \mathrm{M})$. No cotreatments had any effect on their own. Each bar represents the mean of at least three independent experiments. $* P \leq 0.05$, the percentage of early apoptosis or the percentage of late apoptosis/necrosis of the jadomycin or mitoxantrone treatment plus cotreatment was significantly different vs. the jadomycin or mitoxantrone treatment on its own as determined by unpaired $t$ tests (a-d) or one-way ANOVAs followed by Bonferroni multiple-comparison tests (e). $\dagger P \leq 0.05$, the percentage of early apoptosis or the percentage of late apoptosis/necrosis of the jadomycin or mitoxantrone treatment was significantly higher than that of the no-treatment control; $\ddagger P \leq 0.05$, the percentage of early apoptosis or the percentage of late apoptosis/necrosis of the jadomycin or mitoxantrone treatment plus cotreatment is significantly higher than that of the cotreatment alone, as determined by two-way ANOVAs, followed by Bonferroni multiple-comparison tests. 

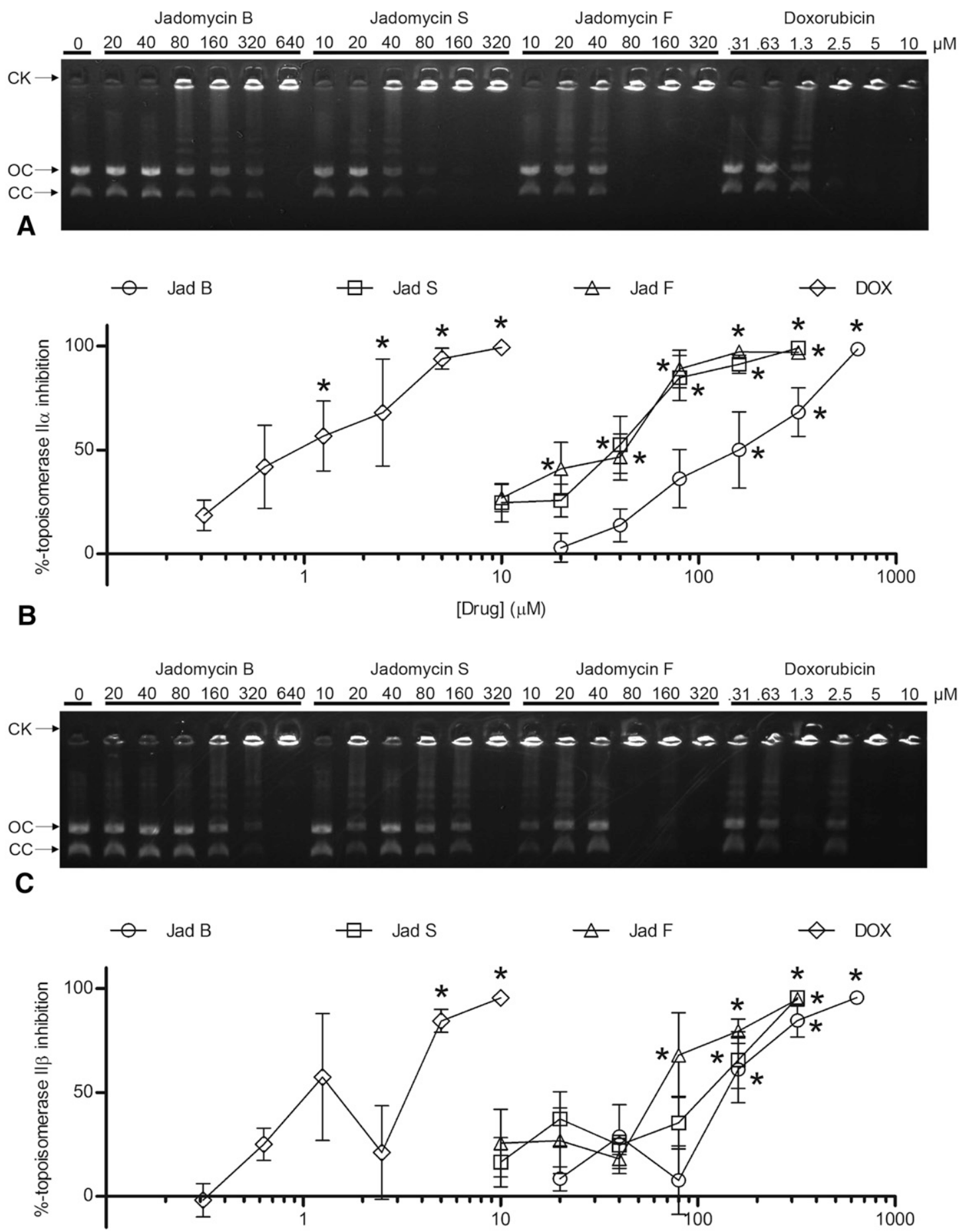

D

[Drug] $(\mu \mathrm{M})$

Fig. 8. The conversion of catenated kDNA circles (CK) to open circular (OC) and closed circular (CC) decatenated kDNA by purified topoisomerase II $\alpha$ (a) or II $\beta$ enzyme (c) was concentration-dependently inhibited by jadomycins (Jads) B, S, and F and DOX. The sizes of the OC and CC bands for each treatment were calculated for each Jad and DOX treatment from which the percentage of inhibition curves for topoisomerase II $\alpha$ (b) or II $\beta$ (d) were generated. Each point represents the mean of at least three independent experiments. ${ }^{*} P \leq 0.05$, the value is significantly different from the vehicle control, as determined by a one-way ANOVA, followed by Bonferroni multiple-comparison test.

Since ROS can induce DNA double-strand breaks (Khanna and Jackson, 2001), we hypothesized that jadomycins would cause double-strand breaks in MDA-MB-231 cells. The increases in $\gamma \mathrm{H} 2 \mathrm{AX}$ observed when 231-CON and 231-TXL cells were treated with jadomycins support this hypothesis. The ability of jadomycin S (but not the ABCB1 substrate mitoxantrone) to retain its $\gamma \mathrm{H} 2 \mathrm{AX}$-inducing effect in 231 TXL cells is consistent with the ability of jadomycins to evade the ABCB1 drug efflux mechanism of MDR (Issa et al., 2014). Interestingly, when 231-CON cells were treated with NAC or auranofin with jadomycin $\mathrm{S}$, there was no additional change in $\gamma \mathrm{H} 2 \mathrm{AX}$ levels, whereas cotreatment with the DNA repair 
TABLE 2

$\mathrm{IC}_{50}$ values of jadomycins $\mathrm{B}, \mathrm{S}$, and $\mathrm{F}$ and DOX for the inhibition of topoisomerases II $\alpha$ and II $\beta$, as measured with $\mathrm{kDNA}$ decatenation assays

Each value represents the mean of at least four independent experiments. No drug treatment was significantly more potent at inhibiting one topoisomerase vs. the other, as determined by a two-way ANOVA followed by Bonferroni multiplecomparison test. Values are the mean \pm S.E.M. IC $_{50}$ values $(\mu M)$.

\begin{tabular}{lcccc}
\hline & \multicolumn{1}{c}{ Jad B } & \multicolumn{1}{c}{ Jad S } & \multicolumn{1}{c}{ Jad F } & \multicolumn{1}{c}{ DOX } \\
\hline Topo II $\alpha$ & $180.0 \pm 47.0^{*}$ & $43.3 \pm 12.7$ & $31.8 \pm 9.8$ & $2.2 \pm 0.6$ \\
Topo II $\beta$ & $146.9 \pm 33.4^{* *}$ & $69.0 \pm 11.0$ & $59.3 \pm 12.3$ & $2.8 \pm 0.9$ \\
\hline
\end{tabular}

Jad, jadomycin; Topo, topoisomerase.

$* P<0.05$, the $\mathrm{IC}_{50}$ value is significantly different from that of $\mathrm{Jad} \mathrm{S}, \mathrm{Jad} \mathrm{F}$, and DOX for the given topoisomerase; ${ }^{*} P<0.05$, the $\mathrm{IC}_{50}$ value is significantly different from that of only DOX for the given topoisomerase.

PARP inhibitor benzamide (Steffen et al., 2011) significantly increased $\gamma \mathrm{H} 2 \mathrm{AX}$ levels. This confirms that jadomycins cause DNA double-strand breaks but also suggests that they occur independently of ROS.

Increased ROS activity and double-strand breaks within cells are common triggers of apoptosis (Kaina, 2003; Bertram and Hass, 2008). Additionally, using chromatin condensation assays $\mathrm{Fu}$ et al. (2008) provided evidence that jadomycin B induces apoptosis in lung carcinoma A549 cells. Therefore, we suspected that jadomycins would also induce apoptosis in breast cancer cells. Our annexin V affinity assays support this idea, showing significantly more early apoptotic 231-CON cells when treated with jadomycins $\mathrm{B}, \mathrm{S}$, or $\mathrm{F}$ versus the vehicle control. Consistent with the results of the $\gamma \mathrm{H} 2 \mathrm{AX}$ assays, the effect of jadomycin $\mathrm{S}$ on apoptosis was not impacted by ABCB1 overexpression, providing further evidence that jadomycins evade ABCB1 efflux. Additionally, jadomycins increased the number of annexin $\mathrm{V}$ and propidium iodide dual-stained cells, signifying cells killed through either apoptosis or necrosis (Greenshields et al., 2015). Therefore, although we can conclude that jadomycins induce apoptosis, we cannot determine whether cell death occurs solely through apoptosis or a combination of cell death mechanisms.

To determine the importance of jadomycin-induced ROS in eliciting apoptosis, annexin $\mathrm{V}$ affinity assays were completed in cells cotreated with NAC or auranofin along with jadomycins. The antioxidant NAC had no effect on jadomycin-induced early apoptosis or late apoptosis/necrosis in 231-CON and 231TXL cells, suggesting that jadomycins induce apoptosis and cell death independently of ROS. Conversely, when the cells were cotreated with auranofin, an increase in late apoptosis/necrosis was observed. However, since auranofin did not increase ROS in 231-TXL cells, this suggests it augmented jadomycin-mediated cell death independently of ROS (perhaps through its inhibition of the DNA repair ubiquitin-proteasome system) (Roder and Thomson, 2015). This contrasts with our previous study, which showed that NAC decreased and auranofin increased jadomycin potency in MCF7 breast cancer cells (Hall et al., 2015). This suggests that ROS may still play a role in jadomycin cytotoxic potency; however, because MCF7 cells are more sensitive to ROS-inducing drugs than MDA-MB231 cells (Kang et al., 2010), their effects may depend on the cell line used.

The greater induction of early apoptosis by jadomycin $\mathrm{S}$ in 231-CON cells and late apoptosis/necrosis in 231-TXL cells when cotreated with benzamide, which inhibits DNA repair PARP proteins (Steffen et al., 2011), further evidences that jadomycin-induced damage of DNA is linked to apoptosis. Additionally, the observation that benzamide altered the potency of jadomycin $\mathrm{S}$ but not of jadomycins B or $\mathrm{F}$ in 231CON cells supports that the apoptotic mechanisms of jadomycins are dependent on their structures. The pan-inhibitor of the apoptotic family of caspases, Z-VAD (Cohen, 1997), lessened jadomycin-induced early apoptosis, suggesting that jadomycins induce caspase-dependent apoptosis. The fact that similar results were seen in 231-TXL versus $231-\mathrm{CON}$ cells with and without the cotreatments indicates that the mechanisms behind jadomycin cytotoxicity are largely preserved in the MDR cell line.

Our $\gamma \mathrm{H} 2 \mathrm{AX}$ and annexin-V affinity assays suggest that jadomycins induce DNA damage and apoptosis in 231-CON and 231-TXL cells through an ROS-independent mechanism. Jadomycins inhibit aurora B kinase independently of ROS (Hall et al., 2015); however, this mechanism is not likely to induce DNA damage since the opposite occurs: DNA damage inhibits aurora B kinase (Monaco et al., 2005). Alternatively, we hypothesized that jadomycins could inhibit topoisomerases. Topoisomerases prevent DNA supercoiling by regulating overwinding and underwinding during cellular processes such as replication and transcription (Pommier et al., 2010), and their inhibition can cause DNA damage and apoptosis (Sordet et al., 2003).

The large decreases in TOP $2 A$ and TOP $2 B$ gene expression caused by jadomycins $\mathrm{B}, \mathrm{S}$, and $\mathrm{F}$, with only a small TOP1 decrease observed with jadomycin $\mathrm{S}$, suggest that jadomycins preferentially inhibit type II versus type I topoisomerase gene expression. The known topoisomerase II inhibitor mitoxantrone (Pommier et al., 2010) slightly increased and decreased TOP $2 A$ and $T O P 2 B$, respectively, while having no effect on TOP1, evidencing that jadomycins more potently inhibit topoisomerase II gene expression than mitoxantrone. The decreased topoisomerase II $\alpha$ enzyme levels, measured through Western blotting, caused by jadomycins in 231-CON and 231-TXL cells suggest that the inhibition of topoisomerase II gene expression decreased protein synthesis and that this mechanism is retained in ABCB1-overexpressing MDR cells, whereas the ABCB1 substrate mitoxantrone (Consoli et al., 1997) lost its inhibitory properties.

The DNA decatenation assays showed that jadomycins B, S, and $\mathrm{F}$ and the topoisomerase II poison DOX (Hasinoff et al., 2016) concentration-dependently inhibited both topoisomerases II $\alpha$ and II $\beta$ with $100 \%$ inhibitory efficacy. The higher $\mathrm{IC}_{50}$ value of jadomycin $\mathrm{B}$ versus those of jadomycins $\mathrm{S}$ and $\mathrm{F}$ for topoisomerase II $\alpha$ suggests that the structural differences of jadomycin analogs can alter their inhibitory potency. The topoisomerase II inhibition IC $_{50}$ values were higher than the concentrations required to inhibit topoisomerase II gene and II $\alpha$ protein levels in cellular assays, and were higher than the $\mathrm{IC}_{50}$ values measured through MTT cell viability assays. This suggests that the reduction of topoisomerase II gene and protein expression would be more likely to occur in breast cancer cells exposed to jadomycins versus direct enzyme inhibition. However, depending on the level of jadomycin accumulation within cells, direct topoisomerase II inhibition is possible.

To determine whether jadomycins are catalytic inhibitors or interfacial poisons of type II topoisomerases, DNA cleavage assays were completed (Burden et al., 2001). Type II topoisomerases covalently bind with cleaved DNA, forming 

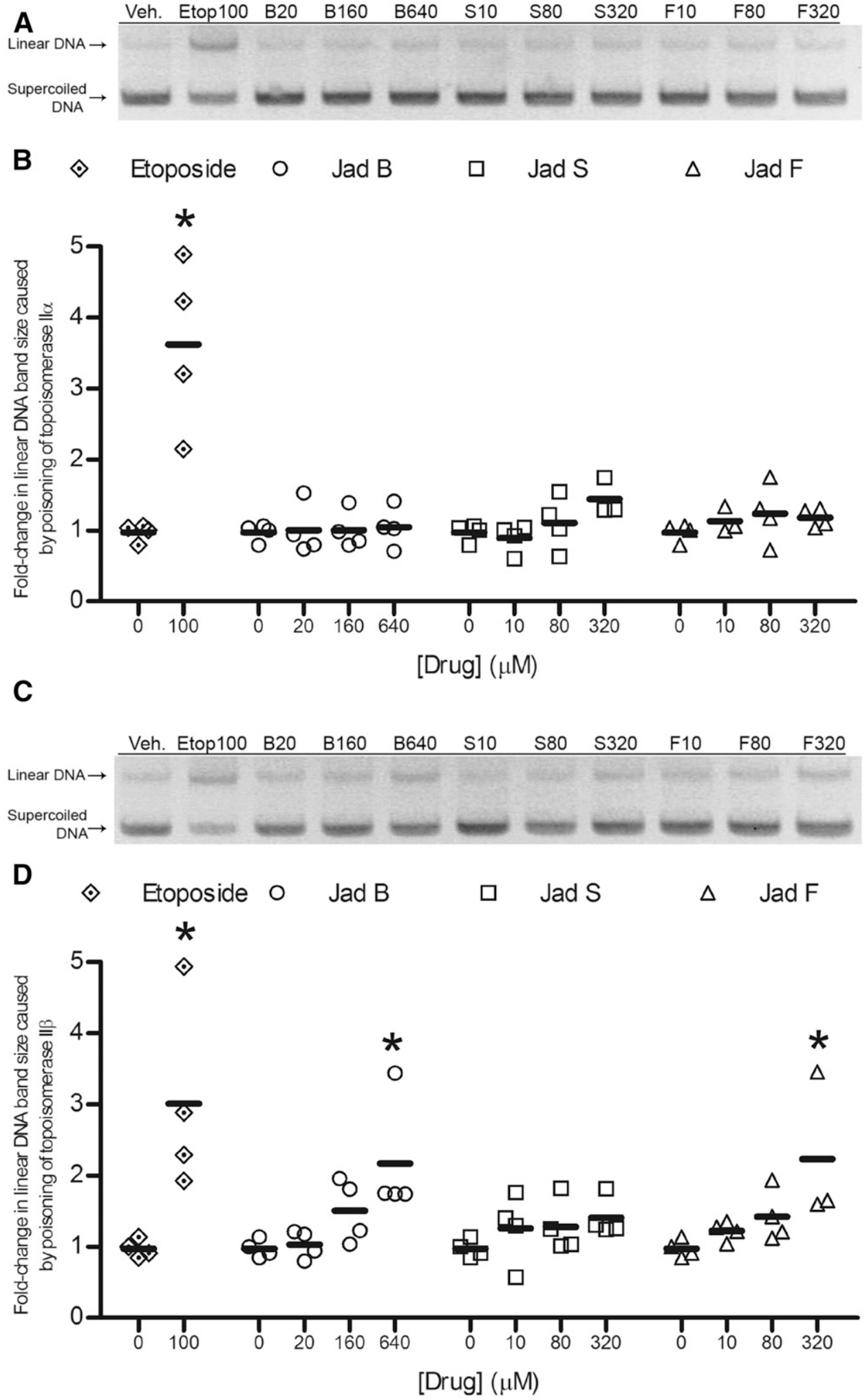

Fig. 9. (a) Inverse-color representative gels show jadomycins (Jads) $\mathrm{B}, \mathrm{S}$, and $\mathrm{F}$ did not alter linear DNA formed from supercoiled pHOT1 DNA in the presence of topoisomerase II $\alpha$ vs. vehicle. (c) Jads B and $\mathrm{F}$ (at 640 and $320 \mu \mathrm{M}$, respectively) increased linear DNA formed by topoisomerase II $\beta$ vs. vehicle (Veh), whereas Jad S had no effect. The positive control etoposide (Etop; $100 \mu \mathrm{M}$ ) increased linear DNA formed by both isoenzymes. Fold changes in linear DNA band size were calculated for each treatment vs. vehicle control for topoisomerases II $\alpha$ (b) and II $\beta$ (d). ${ }^{*} P \leq 0.05$, the value is significantly different from the vehicle control $(0 \mu \mathrm{M})$ as determined by an unpaired $t$ test (etoposide) or one-way ANOVAs (Jads), followed by Bonferroni multiple-comparison test. cleavage complexes, which are normally short-lived intermediates. Topoisomerase poisons, like etoposide, trap topoisomerases in these topoisomerase II-DNA cleavage complexes, causing cell-lethal DNA strand breaks and converting these essential enzymes into potent toxins (Lindsey et al., 2004). High concentrations of jadomycins $\mathrm{B}$ and $\mathrm{F}$ increased the formation of linear DNA from supercoiled pHOT1 DNA when incubated with topoisomerase II $\beta$, but not II $\alpha$, suggesting that they are selective topoisomerase II $\beta$ poisons. In contrast, jadomycin $\mathrm{S}$ did not increase the formation of cleaved plasmid DNA by either isoenzyme, suggesting that it does not poison type II topoisomerases. These results raise some concern for 
jadomycins $\mathrm{B}$ and $\mathrm{F}$, since, despite the potent anticancer activity of topoisomerase II poisons, their use in cancer patients has been linked to the development of secondary malignancies, like acute myeloid leukemia (Nitiss, 2009), and topoisomerase II $\beta$-poisons have been correlated with significant cardiotoxicity, as observed with anthracyclines (Lyu et al., 2007; Sawyer, 2013). Alternatively, the lack of topoisomerase II poisoning by jadomycin S could be advantageous from an adverse drug reaction perspective, especially considering that it is equally potent against breast cancer cells compared with other jadomycins (Issa et al., 2014; Hall et al., 2015). However, this remains to be determined in future in vivo studies.

In conclusion, jadomycins demonstrate potential as novel treatments for drug-resistant breast cancer by retaining their cytotoxic potency in MDR, triple-negative 231-TXL cells and as previously described in MDR MCF7 cells (Issa et al., 2014). We have also demonstrated that jadomycins exert their anticancer activity in 231-CON and 231-TXL cells through a novel ROS-independent mechanism that leads to DNA doublestrand breaks and apoptosis. Through further investigation, we discovered that jadomycins inhibit the gene and protein expressions of the validated anticancer targets topoisomerases II $\alpha$ and II $\beta$ (Pommier et al., 2010) and act as type II topoisomerase catalytic inhibitors and, in some cases, interfacial poisons, thus advancing our understanding of the mechanisms of action of jadomycins. However, further studies are needed to establish the functional link between the inhibition of type II topoisomerases by jadomycins and ROSindependent DNA damage and apoptosis in breast cancer cells, and their safety and effectiveness in the treatment of MDR breast cancer in animal models.

\section{Acknowledgments}

We thank Dr. David Hoskin and Dr. Anna Greenshields for providing the 231-CON cell line, Dr. Greenshields for training S.R.H. on the annexin V affinity assays, Dr. Dale Corkery for his expertise on the $\gamma \mathrm{H} 2 \mathrm{AX}$ measurement assays, and Dr. Neil Osheroff and Jo Ann Byl for providing the purified topoisomerase II $\beta$.

\section{Authorship Contributions}

Participated in research design: Hall and Goralski.

Conducted experiments: Hall, Toulany, and Bennett.

Contributed new reagents or analytical tools: Martinez-Farina,

Robertson, and Jakeman.

Performed data analysis: Hall and Goralski.

Wrote or contributed to the writing of the manuscript: Hall and Goralski.

\section{References}

Bandele OJ and Osheroff N (2009) Cleavage of plasmid DNA by eukaryotic topoisomerase II. Methods Mol Biol 582:39-47.

Bauer KR, Brown M, Cress RD, Parise CA, and Caggiano V (2007) Descriptive analysis of estrogen receptor (ER)-negative, progesterone receptor (PR)-negative, and HER2-negative invasive breast cancer, the so-called triple-negative phenotype: a population-based study from the California cancer Registry. Cancer 109: 1721-1728.

Bertram C and Hass R (2008) Cellular responses to reactive oxygen species-induced DNA damage and aging. Biol Chem 389:211-220.

Burden DA, Froelich-Ammon SJ, and Osheroff N (2001) Topoisomerase II-mediated cleavage of plasmid DNA. Methods Mol Biol 95:283-289.

Cohen GM (1997) Caspases: the executioners of apoptosis. Biochem $J$ 326:1-16.

Consoli U, Van NT, Neamati N, Mahadevia R, Beran M, Zhao S, and Andreeff M (1997) Cellular pharmacology of mitoxantrone in p-glycoprotein-positive and -negative human myeloid leukemic cell lines. Leukemia 11:2066-2074.

Dodd S, Dean O, Copolov DL, Malhi GS, and Berk M (2008) N-acetylcysteine for antioxidant therapy: pharmacology and clinical utility. Expert Opin Biol Ther 8: 1955-1962.
Dupuis SN, Veinot T, Monro SM, Douglas SE, Syvitski RT, Goralski KB, McFarland SA, and Jakeman DL (2011) Jadomycins derived from the assimilation and incorporation of norvaline and norleucine. J Nat Prod 74:2420-2424.

Dupuis SN, Robertson AW, Veinot T, Monro SMA, Douglas SE, Syvitski RT, Goralski KB, McFarland SA, and Jakeman DL (2012) Synthetic diversification of natura products: semi-synthesis and evaluation of triazole jadomycins. Chem Sci 3: 1640-1644.

Elias AD (2010) Triple-negative breast cancer: a short review. Am J Clin Oncol 33: $637-645$

Fu DH, Jiang W, Zheng JT, Zhao GY, Li Y, Yi H, Li ZR, Jiang JD, Yang KQ, Wang Y, et al. (2008) Jadomycin B, an Aurora-B kinase inhibitor discovered through virtual screening. Mol Cancer Ther 7:2386-2393.

Greenshields AL, Doucette CD, Sutton KM, Madera L, Annan H, Yaffe PB, Knickle AF, Dong Z, and Hoskin DW (2015) Piperine inhibits the growth and motility of triple-negative breast cancer cells. Cancer Lett 357:129-140.

Hall SR, Blundon HL, Ladda MA, Robertson AW, Martinez-Farina CF, Jakeman DL, and Goralski KB (2015) Jadomycin breast cancer cytotoxicity is mediated by a copper-dependent, reactive oxygen species-inducing mechanism. Pharmacol Res Perspect 3:e00110.

Hasinoff BB, Creighton AM, Kozlowska H, Thampatty P, Allan WP, and Yalowich JC (1997) Mitindomide is a catalytic inhibitor of DNA topoisomerase II that acts at the bisdioxopiperazine binding site. Mol Pharmacol 52:839-845.

Hasinoff BB, Wu X, Patel D, Kanagasabai R, Karmahapatra S, and Yalowich JC (2016) Mechanisms of action and reduced cardiotoxicity of pixantrone; a topoisomerase II targeting agent with cellular selectivity for the topoisomerase II $\alpha$ isoform. J Pharmacol Exp Ther 356:397-409.

Issa ME, Hall SR, Dupuis SN, Graham CL, Jakeman DL, and Goralski KB (2014) Jadomycins are cytotoxic to ABCB1-, ABCC1-, and ABCG2-overexpressing MCF7 breast cancer cells. Anticancer Drugs 25:255-269.

Jakeman DL, Graham CL, Young W, and Vining LC (2006) Culture conditions improving the production of jadomycin B. J Ind Microbiol Biotechnol 33:767-772.

Jakeman DL, Dupuis SN, and Graham CL (2009) Isolation and characterization of jadomycin L from Streptomyces venezuelae ISP5230 for solid tumor efficacy studies. Pure Appl Chem 81:1041-1049.

Kaina B (2003) DNA damage-triggered apoptosis: critical role of DNA repair, doublestrand breaks, cell proliferation and signaling. Biochem Pharmacol 66:1547-1554. Kang KS, Wang P, Yamabe N, Fukui M, Jay T, and Zhu BT (2010) Docosahexaenoic acid induces apoptosis in MCF-7 cells in vitro and in vivo via reactive oxygen species formation and caspase 8 activation. PLoS One 5:e10296.

Khanna KK and Jackson SP (2001) DNA double-strand breaks: signaling, repair and the cancer connection. Nat Genet 27:247-254.

Kuo LJ and Yang LX (2008) Gamma-H2AX - a novel biomarker for DNA doublestrand breaks. In Vivo 22:305-309.

Lindsey RH, Jr, Bromberg KD, Felix CA, and Osheroff N (2004) 1,4-Benzoquinone is a topoisomerase II poison. Biochemistry 43:7563-7574.

Liu C, Liu Z, Li M, Li X, Wong YS, Ngai SM, Zheng W, Zhang Y, and Chen T (2013) Enhancement of auranofin-induced apoptosis in MCF-7 human breast cells by selenocystine, a synergistic inhibitor of thioredoxin reductase. PLoS One 8:e53945.

Liu LF (1989) DNA topoisomerase poisons as antitumor drugs. Annu Rev Biochem 58:351-375.

Livak KJ and Schmittgen TD (2001) Analysis of relative gene expression data using real-time quantitative PCR and the 2(-Delta Delta C(T)) Method. Methods 25: $402-408$.

Lluch A, Alvarez I, Muñoz M, Seguí MA, Tusquets I, and García-Estévez L (2014) Treatment innovations for metastatic breast cancer: nanoparticle albumin-bound (NAB) technology targeted to tumors. Crit Rev Oncol Hematol 89:62-72.

Lowry OH, Rosebrough NJ, Farr AL, and Randall RJ (1951) Protein measurement with the Folin phenol reagent. J Biol Chem 193:265-275.

Lyu YL, Kerrigan JE, Lin CP, Azarova AM, Tsai YC, Ban Y, and Liu LF (2007) Topoisomerase Ilbeta mediated DNA double-strand breaks: implications in doxorubicin cardiotoxicity and prevention by dexrazoxane. Cancer Res 67:8839-8846.

Marchand C and Pommier Y (2012) Topoisomerase inhibitors: a paradigm for interfacial inhibition, in DNA Topoisomerases and Cancer (Pommier Y, ed), pp 175-184, Springer, New York

Martinez-Farina CF and Jakeman DL (2015) Jadomycins, put a bigger ring in it: isolation of seven- to ten-membered ring analogues. Chem Commun (Camb) 51: 14617-14619.

Martinez-Farina CF, McCormick N, Robertson AW, Clement H, Jee A, Ampaw A, Chan NL, Syvitski RT, and Jakeman DL (2015) Investigations into the binding of jadomycin DS to human topoisomerase II $\beta$ by WaterLOGSY NMR spectroscopy. Org Biomol Chem 13:10324-10327.

Monaco L, Kolthur-Seetharam U, Loury R, Murcia JM, de Murcia G, and SassoneCorsi P (2005) Inhibition of Aurora-B kinase activity by poly(ADP-ribosyl)ation in response to DNA damage. Proc Natl Acad Sci USA 102:14244-14248.

Morris PG, McArthur HL, and Hudis CA (2009) Therapeutic options for metastatic breast cancer. Expert Opin Pharmacother 10:967-981.

Nitiss JL (2009) Targeting DNA topoisomerase II in cancer chemotherapy. Nat Rev Cancer 9:338-350.

Pommier Y, Leo E, Zhang H, and Marchand C (2010) DNA topoisomerases and their poisoning by anticancer and antibacterial drugs. Chem Biol 17:421-433.

Rakha EA, El-Sayed ME, Green AR, Lee AH, Robertson JF, and Ellis IO (2007) Prognostic markers in triple-negative breast cancer. Cancer 109:25-32.

Rivera E (2010) Implications of anthracycline-resistant and taxane-resistant metastatic breast cancer and new therapeutic options. Breast $J$ 16:252-263.

Robertson AW, Martinez-Farina CF, Smithen DA, Yin H, Monro S, Thompson A, McFarland SA, Syvitski RT, and Jakeman DL (2015) Eight-membered ringcontaining jadomycins: implications for non-enzymatic natural products biosynthesis. J Am Chem Soc 137:3271-3275.

Roder C and Thomson MJ (2015) Auranofin: repurposing an old drug for a golden new age. Drugs $R$ D 15:13-20. 
Sahai BM and Kaplan JG (1986) A quantitative decatenation assay for type II topoisomerases. Anal Biochem 156:364-379.

Sawyer DB (2013) Anthracyclines and heart failure. N Engl J Med 368:1154-1156.

Shen F, Chu S, Bence AK, Bailey B, Xue X, Erickson PA, Montrose MH, Beck WT, and Erickson LC (2008) Quantitation of doxorubicin uptake, efflux, and modulation of multidrug resistance (MDR) in MDR human cancer cells. J Pharmacol Exp Ther 324:95-102.

Sordet O, Khan QA, Kohn KW, and Pommier Y (2003) Apoptosis induced by topoisomerase inhibitors. Curr Med Chem Anticancer Agents 3:271-290.

Steffen JD, Coyle DL, Damodaran K, Beroza P, and Jacobson MK (2011) Discovery and structure-activity relationships of modified salicylanilides as cell permeable inhibitors of poly(ADP-ribose) glycohydrolase (PARG). $J$ Med Chem 54:5403-5413.

Szakács G, Paterson JK, Ludwig JA, Booth-Genthe C, and Gottesman MM (2006) Targeting multidrug resistance in cancer. Nat Rev Drug Discov 5:219-234. van Engeland M, Nieland LJ, Ramaekers FC, Schutte B, and Reutelingsperger CP (1998) Annexin V-affinity assay: a review on an apoptosis detection system based on phosphatidylserine exposure. Cytometry 31:1-9.

Yu KD, Huang S, Zhang JX, Liu GY, and Shao ZM (2013) Association between delayed initiation of adjuvant CMF or anthracycline-based chemotherapy and survival in breast cancer: a systematic review and meta-analysis. BMC Cancer 13: 240 .

Address correspondence to: Dr. Kerry B. Goralski, College of Pharmacy, Dalhousie University, 5968 College St., PO Box 15000, Halifax, Nova Scotia B3H 4R2, Canada. E-mail: kerry.goralski@dal.ca 